\title{
Sources and mixing state of summertime background aerosol in the north-western Mediterranean basin
}

\author{
Jovanna Arndt ${ }^{1}$, Jean Sciare ${ }^{2,3}$, Marc Mallet ${ }^{4}$, Greg C. Roberts ${ }^{4,5}$, Nicolas Marchand ${ }^{6}$, Karine Sartelet ${ }^{7}$, \\ Karine Sellegri $^{8}$, François Dulac ${ }^{2}$, Robert M. Healy ${ }^{9}$, and John C. Wenger ${ }^{1}$ \\ ${ }^{1}$ Department of Chemistry and Environmental Research Institute, University College Cork, Cork, Ireland \\ ${ }^{2}$ LSCE, Laboratoire des Sciences du Climat et de l'Environnement, Unité Mixte CEA-CNRS-UVSQ, Univ. Paris-Saclay, \\ CEA Saclay/Orme des Merisiers 701, 91191 Gif-sur-Yvette, France \\ ${ }^{3}$ Energy, Environment and Water Research Center, The Cyprus Institute, 2121 Nicosia, Cyprus \\ ${ }^{4}$ CNRM, Centre National de Recherches Météorologiques UMR 3589, Météo-France/CNRS, Toulouse, France \\ ${ }^{5}$ Scripps Institution of Oceanography, Center for Atmospheric Sciences and Physical Oceanography, La Jolla, USA \\ ${ }^{6}$ Aix Marseille Univ, CNRS, LCE, Marseille, France \\ ${ }^{7}$ CEREA, Centre d'Enseignement et de Recherche en Environnement Atmosphérique, \\ Joint Laboratory ENPC ParisTech/EDF R\&D, Université Paris-Est, Marne la Vallée, France \\ ${ }^{8}$ LaMP, Laboratoire de Météorologie Physique CNRS UMR6016, Observatoire de Physique du Globe de Clermont-Ferrand, \\ Université Blaise Pascal, Aubière, France \\ ${ }^{9}$ Environmental Monitoring and Reporting Branch, Ontario Ministry of the Environment and Climate Change, \\ Toronto, Canada
}

Correspondence to: John C. Wenger (j.wenger@ucc.ie)

Received: 23 November 2016 - Discussion started: 8 February 2017

Revised: 9 May 2017 - Accepted: 12 May 2017 - Published: 14 June 2017

\begin{abstract}
An aerosol time-of-flight mass spectrometer (ATOFMS) was employed to provide real-time single particle mixing state and thereby source information for aerosols impacting the western Mediterranean basin during the ChArMEx-ADRIMED and SAF-MED campaigns in summer 2013. The ATOFMS measurements were made at a ground-based remote site on the northern tip of Corsica.

Twenty-seven distinct ATOFMS particle classes were identified and subsequently grouped into eight general categories: EC-rich (elemental carbon), K-rich, Na-rich, amines, OC-rich (organic carbon), V-rich, Fe-rich and Carich particles. Mass concentrations were reconstructed for the ATOFMS particle classes and found to be in good agreement with other co-located quantitative measurements $\left(\mathrm{PM}_{1}\right.$, black carbon (BC), organic carbon, sulfate mass and ammonium mass). Total ATOFMS reconstructed mass $\left(\mathrm{PM}_{2.5}\right)$ accounted for $70-90 \%$ of measured $\mathrm{PM}_{10}$ mass and was comprised of regionally transported fossil fuel (EC-rich) and biomass burning (K-rich) particles. The accumulation of these transported particles was favoured by repeated and
\end{abstract}

extended periods of air mass stagnation over the western Mediterranean during the sampling campaigns. The single particle mass spectra proved to be valuable source markers, allowing the identification of fossil fuel and biomass burning combustion sources, and was therefore highly complementary to quantitative measurements made by Particle into Liquid Sampler ion chromatography (PILS-IC) and an aerosol chemical speciation monitor (ACSM), which have demonstrated that $\mathrm{PM}_{1}$ and $\mathrm{PM}_{10}$ were comprised predominantly of sulfate, ammonium and OC. Good temporal agreement was observed between ATOFMS EC-rich and K-rich particle mass concentrations and combined mass concentrations of BC, sulfate, ammonium and low volatility oxygenated organic aerosol (LV-OOA). This combined information suggests that combustion of fossil fuels and biomass produced primary EC- and OC-containing particles, which then accumulated ammonium, sulfate and alkylamines during regional transport.

Three other sources were also identified: local biomass burning, marine and shipping. Local combustion particles 
(emitted in Corsica) contributed little to $\mathrm{PM}_{2.5}$ particle number and mass concentrations but were easily distinguished from regional combustion particles. Marine emissions comprised fresh and aged sea salt: the former was detected mostly during a 5-day event during which it accounted for $50-80 \%$ of sea salt aerosol mass, while the latter was detected throughout the sampling period. Dust was not efficiently detected by the ATOFMS, and support measurements showed that it was mainly in the $\mathrm{PM}_{2.5-10}$ fraction. Shipping particles, identified using markers for heavy fuel oil combustion, were associated with regional emissions and represented only a small fraction of $\mathrm{PM}_{2.5}$ particle number and mass concentration at the site.

\section{Introduction}

The atmosphere in the Mediterranean basin is strongly influenced by numerous and varied aerosol sources. Anthropogenic emissions from heavily industrialised parts of southern Europe (e.g. Genoa and Milan), the megacities of Istanbul and Cairo, a large range of smaller population centres disseminated all over the basin, as well as intense shipping activities render the Mediterranean basin one of the most airpollution-impacted zones on the planet (Karanasiou et al., 2014; de la Paz et al., 2013). Natural sources such as Saharan dust, sea-spray and frequent forest fires exert further considerable stress on regional air quality (Kanakidou et al., 2011). Transport of air pollution from outside the Mediterranean region is one cause for increased concentrations of primary and secondary pollutants (Lelieveld et al., 2002). In the summertime upper troposphere, Asian monsoon outflow transports pollution across northern Africa and the Mediterranean (Scheeren et al., 2003). In the middle troposphere, westerly winds prevail, transporting polluted air masses from western Europe and North America (Marmer and Langmann, 2005). In the surface layer, land emissions from southern and central Europe are transported to the eastern Mediterranean by northerly winds (Sciare et al., 2003).

The geography and regional meteorological processes in the western Mediterranean also favour the accumulation and ageing of polluted air masses (Gangoiti et al., 2001; Lelieveld et al., 2002; Millán et al., 2000, 2002; Millán and Salvador, 1997; Rodríguez et al., 2002; Salvador et al., 1999; Soriano et al., 2001). Arid conditions, combined with high solar radiation and photochemical conversion rates significantly enhance air pollution mostly in the form of $\mathrm{PM}_{2.5}$ and $\mathrm{O}_{3}$. The highest particulate matter (PM) concentrations are generally found in southern and eastern Europe and attributed to diverse emission sources such as industry, traffic, resuspended dust, shipping emissions and African dust intrusions (Karanasiou et al., 2011, 2014, 2007, 2009; Lelieveld et al., 2002; Querol et al., 2004; Rodríguez et al., 2007; Salameh et al., 2015). A number of studies have reported that in rural environments in the Mediterranean, airborne PM and ammonium sulfate concentrations undergo a seasonal cycle characterised by a summer maximum (Bergametti et al., 1989; Kubilay and Saydam, 1995; Querol et al., 1998a, b; Rodríguez et al., 2001, 2002). This seasonal cycle has not been reported at rural sites in central and northern Europe, where high PM events are mostly recorded in winter during stagnant episodes caused by cold temperature inversions and low wind speed (Beekmann et al., 2015; Favez et al., 2007; Monn et al., 1995; Röösli et al., 2001; Turnbull and Harrison, 2000). Long-term measurements at sites in the western and eastern Mediterranean basin by Querol et al. (2009) showed that mineral matter is the major component of $\mathrm{PM}_{10}(22-38 \%)$ in both areas, with relatively high proportions in $\mathrm{PM}_{2.5}$ (8$14 \%)$, followed by sulfate, organic matter (OM), nitrate and ammonium.

Most studies to date have documented Mediterranean aerosol properties in the eastern basin or at coastal continentbased sites in the western basin, where they were subject to the proximity of considerable urban or industrial emissions. Land-based measurements of the background composition of western Mediterranean atmospheric aerosol is best investigated on the shoreline of relatively industryfree, less urbanised islands and studies in such locations have thus far been limited. One of the central aims of the ChArMEx (Chemistry-Aerosol Mediterranean Experiment; https://charmex.lsce.ipsl.fr) project is to make background aerosol observations on islands such as Corsica and the Balearic Islands.

In addition, studies of the chemical composition of single aerosol particles in the Mediterranean are particularly scarce and are restricted to urban environments (Dall'Osto et al., 2013, 2016; Dall'Osto and Harrison, 2006; McGillicuddy, 2014). Single particle mass spectrometers, such as the aerosol time-of-flight mass spectrometer (ATOFMS), have proven valuable in identifying and characterising a wide variety of particle sources: sea salt, mineral dust, vehicle exhaust, tyre wear, solid fuel combustion (coal, peat and wood), shipping and various industrial emissions (Beddows et al., 2004; Bhave et al., 2001, 2002; Dall'Osto et al., 2014; Giorio et al., 2012; Harrison et al., 2012; Healy et al., 2009, 2010, 2012; Liu et al., 2003; Spencer et al., 2008; Tao et al., 2011). Mixing state information - both internal and external - provided by mass spectrometers has been used to determine the type of atmospheric processing particles have undergone (Gard et al., 1998), as well as their acidity and hygroscopicity (Denkenberger et al., 2007; Healy et al., 2014), properties which affect their ability to act as CCN (cloud condensation nuclei; Furutani et al., 2008). The combination of ATOFMS and hygroscopicity tandem differential mobility analyser (HTDMA) data has shown that sea salt and particles containing amines and nitrate are hydrophilic, while the more organic carbon (OC) particles contain the more hydrophobic they are (Herich et al., 2009; Wang et al., 2014). Fresh particles can be distinguished from aged ones by the presence 
of secondary inorganic species such as nitrate, sulfate and ammonium (Cahill et al., 2012; Healy et al., 2010; Liu et al., 2003; Pratt and Prather, 2009), which is also helpful in differentiating particles from local and transported sources (Healy et al., 2012). Single particle chemical speciation is therefore a useful tool for examining the effect aerosols have on air quality and climate, and is complementary to characterising particle optical and physical properties (Moffet and Prather, 2009). Measurements from the ATOFMS also provide useful information to validate mixing-state resolved models (Zhu et al., 2016). In air quality and climate models, mixing-state information is essential as this property strongly impacts aerosol composition, hygroscopicity, optical and CCN properties over urban areas (Zhu et al., 2016).

An important application of single-particle data is source apportionment of ambient aerosol. If a unique particle composition signature can be linked to a specific source, then number and mass concentration contributions can be estimated at a receptor site (Allen et al., 2000; Bein et al., 2006; Pratt and Prather, 2009; Qin et al., 2006; Reinard et al., 2007). Most chemical speciation measurements to date in the Mediterranean have focused on bulk aerosol and, while they provide quantitative data, they do not resolve the mixing states of ambient particles. As such, source identification and therefore apportionment - often one of the main goals of aerosol measurements - is limited with these techniques.

In this context, an aerosol time-of-flight mass spectrometer (ATOFMS) was employed to provide real-time single particle mixing state and thereby source information for aerosols impacting the western Mediterranean basin during two ChArMEx special observation periods in summer 2013: ADRIMED (Aerosol Direct Radiative Impact on the regional climate in the MEDiterranean region; Mallet et al., 2016) and SAF-MED (Secondary Aerosol Formation in the MEDiterranean).

\section{Methodology}

\subsection{Sampling site and instrumentation}

Measurements were performed at the atmospheric monitoring station in Ersa (coordinates: $42^{\circ} 58^{\prime} 09^{\prime \prime} \mathrm{N}, 09^{\circ} 22^{\prime} 49^{\prime \prime} \mathrm{E}$ ), Cap Corse, near the northern tip of Corsica. This station is well positioned to investigate polluted air masses transported over the western Mediterranean basin from the highly industrialised regions of the Po Valley (Royer et al., 2010) and/or Marseille/Fos-Berre (El Haddad et al., 2011, 2013). The site was fully equipped for the measurement of aerosol chemical, physical and optical properties. This ground-based remote station is located at an altitude of $530 \mathrm{~m}$ a.s.l. at the remote Cap Corse peninsula and has unobstructed views to the sea over $\sim 270^{\circ}$ (Lambert et al., 2011).

The ADRIMED and SAF-MED field campaigns took place from 11 June to 5 July and from 12 July to $6 \mathrm{Au}-$ gust 2013 respectively, during the Mediterranean dry season over the western and central Mediterranean basins. Some of the key instruments deployed during the campaigns are given in Table 1. A full list of instruments deployed during ADRIMED can be found in the overview for this campaign by Mallet et al. (2016), while a summary of the main findings of the SAF-MED campaign is currently in preparation.

The ATOFMS (TSI model 3800) was operated continuously from 12 June to 6 August, with a period of downtime from 12 to 18 July. A detailed description of the ATOFMS can be found elsewhere (Gard et al., 1997). Briefly, it consists of (i) an aerodynamic focusing lens (TSI AFL100) (Su et al., 2004) that transmits particles in the aerodynamic diameter $\left(D_{\mathrm{a}}\right)$ range $100-3000$, (ii) a particle sizing region, and (iii) a bipolar reflectron time-of-flight mass spectrometer. Single particles are desorbed/ionised using a pulsed Nd:YAG laser $\left(\lambda=266 \mathrm{~nm}, \sim 1 \mathrm{~mJ}\right.$ pulse $\left.^{-1}\right)$. Positive and negative ion mass spectra of individual aerosol particles are obtained, which enable identification of the chemical constituents. A gradual degradation in the power of the sizing lasers during the campaign was observed and resulted in effective size ranges of 300-3000 $\mathrm{nm} D_{\mathrm{a}}$ for ADRIMED and 500-3000 nm $D_{\mathrm{a}}$ for SAF-MED.

\subsection{ATOFMS data analysis}

Over 1.2 million single particle mass spectra were generated by the ATOFMS during the sampling period and clustered using the $\mathrm{K}$-means algorithm $(\mathrm{K}=80)$, described in detail elsewhere (Gross et al., 2010; Healy et al., 2009, 2010). Clusters exhibiting very similar average mass spectra (including those with the same major ions but varying relative signal intensities), comparable temporal trends and size distributions were merged. The final merged clusters were then identified as particle classes -27 in total.

The particle class labelling scheme used herein is regularly used in the literature (Dall'Osto and Harrison, 2006; Spencer and Prather, 2006; Ault et al., 2010; Pratt and Prather, 2012) and indicates either the probable source (e.g. sea salt) or the dominant species in the positive ion mass spectra (e.g. K, $\mathrm{EC}, \mathrm{Fe}$ ), with the order of the ions indicating their relative mass spectral intensities. For example, a particle class with high-intensity mass spectral features for sodium and elemental carbon is labelled Na-EC. In some cases this is followed by a secondary species detected in the negative mass spectra (e.g. $\mathrm{K}^{-\mathrm{NO}_{x}}$ ), which usually provides insight into the atmospheric ageing the particles have undergone locally or during transport (Reinard et al., 2007).

Single-particle mass spectrometers such as the ATOFMS do not provide quantitative information in the form of particle number or mass concentrations - rather the ATOFMS provides speciation in particle counts classified by aerodynamic diameter. The transmission biases of the AFL (aerodynamic focusing lens), the number of particles the system can size and ionise at any given time (data acquisition busy 
Table 1. List of instruments deployed at Cap Corsica during the ADRIMED and SAF-MED field campaigns. See text for instrument definitions.

\begin{tabular}{|c|c|c|c|c|}
\hline Parameter & Instrument & Make and model & $\begin{array}{l}\text { Temporal } \\
\text { resolution }\end{array}$ & Institution \\
\hline \multirow{2}{*}{$\begin{array}{l}\text { Particle number size distribution } \\
(10-500 \mathrm{~nm} \text {, mobility diameter and } \\
300 \mathrm{~nm}-20 \mu \mathrm{m} \text {, optical diameter) }\end{array}$} & SMPS & $\begin{array}{l}\text { TSI Instruments Ltd., DMA model } \\
3080 \text { and CPC model } 3010\end{array}$ & $\begin{array}{l}5 \text { min } \\
\text { (continuous) }\end{array}$ & CNRM GAME \\
\hline & OPS & TSI Instruments Ltd., model 3300 & $\begin{array}{l}5 \text { min } \\
\text { (continuous) }\end{array}$ & CNRM GAME \\
\hline $\mathrm{PM}_{10}$ and $\mathrm{PM}_{1}$ mass concentration & $\begin{array}{l}\text { TEOM, } \\
\text { TEOM-FDS }\end{array}$ & & continuous & LSCE \\
\hline $\begin{array}{l}\text { Chemical composition and size distri- } \\
\text { bution of non-refractory and refractory } \\
\text { particles (100-3000 nm, vacuum aero- } \\
\text { dynamic diameter) }\end{array}$ & ATOFMS & $\begin{array}{l}\text { TSI Instruments Ltd., model 3800- } \\
100\end{array}$ & continuous & UCC \\
\hline $\begin{array}{l}\text { Chemical composition of non- } \\
\text { refractory particles }(30-1000 \mathrm{~nm} \text {, } \\
\text { vacuum aerodynamic diameter })\end{array}$ & ACSM & Aerodyne Research Inc. & $\begin{array}{l}25 \min \\
\text { (continuous) }\end{array}$ & LSCE \\
\hline Black carbon (BC), $\mathrm{PM}_{2.5}$ & MAAP & Thermo-Scientific, model 5012 & $\begin{array}{l}5 \text { min } \\
\text { (continuous) }\end{array}$ & LSCE \\
\hline $\begin{array}{l}\mathrm{PM}_{10} \text { chemical composition } \mathrm{Ca}^{+}, \\
\mathrm{Mg}^{+}, \mathrm{Cl}^{-}, \mathrm{Ca}^{2+}, \mathrm{K}^{+}, \mathrm{NH}_{4}^{+}, \mathrm{NO}_{2}^{-}, \\
\left.\mathrm{SO}_{4}^{2-}, \mathrm{MSA}, \text { Oxalate }\right)\end{array}$ & PILS-IC & & $\begin{array}{l}12 / 18 \min \\
\text { (continuous) }\end{array}$ & LSCE \\
\hline $\begin{array}{l}\text { Pressure, temperature, relative humid- } \\
\text { ity, solar radiation, rain, wind speed and } \\
\text { direction }\end{array}$ & $\begin{array}{l}\text { Weather } \\
\text { station }\end{array}$ & $\begin{array}{l}\text { Campbell Scientific, } \\
\text { CR1000 }\end{array}$ & $\begin{array}{l}5 \text { min } \\
\text { (continuous) }\end{array}$ & LSCE \\
\hline
\end{tabular}

UCC: University College Cork. LSCE: Laboratoire des Sciences du Climat et de l’Environnement. CNRM-GAME : Centre National de Recherches Météorologiques Groupe d'étude de l'Atmosphère Météorologique.

time) and a limited detection of particles $<150 \mathrm{~nm}$ (determined by wavelength of sizing lasers and the amount of scattered light) hinder a full and accurate counting of particles over the entire ATOFMS size range (100-3000 nm $D_{\mathrm{a}}$ ). The desorption/ionisation laser used by the ATOFMS also complicates quantitative speciation. Shot-to-shot fluctuations in laser output power and variations in power density (Gaussian) across the laser beam (Steele et al., 2005; Wenzel and Prather, 2004) create variance in the amount of a particle that is desorbed and can also lead to variations in resultant mass spectral peak height and area (Reinard and Johnston, 2008).

Given these limitations, in order to produce meaningful particle number and mass concentrations for ATOFMS particle classes the total ATOFMS counts were scaled using quantitative particle counting instruments operated concurrently: an optical particle counter (OPC, TSI model 3300) and a scanning mobility particle sizer (SMPS, TSI DMA model 3080 and CPC model 3010). Reconciling SMPS, OPS and ATOFMS data requires conversion of $D_{\mathrm{m}}$ (electrical mobility diameter; SMPS) and $D_{\mathrm{O}}$ (optical diameter; OPC) measured with the SMPS and OPS into the corresponding ATOFMS $D_{\mathrm{a}}$ (aerodynamic diameter), using the following relationship:

$D_{\mathrm{a}}=\frac{\rho_{\mathrm{p}}}{\rho_{0}} \frac{D_{\mathrm{ve}}}{\chi}$,

where $\rho_{\mathrm{p}}$ is the particle density (discussed hereafter), $D_{\mathrm{ve}}$ is the volume equivalent diameter (operationally equivalent to $D_{\mathrm{m}}$ or $\left.D_{\mathrm{o}}\right), \rho_{0}$ is standard density $\left(1 \mathrm{~g} \mathrm{~cm}^{-3}\right)$ and $\chi$ is the dynamic shape factor (assumed to be 1, thus representing spherical shape). This is a simplified version of particle diameter, morphology and density relationships that are covered in much greater detail elsewhere (DeCarlo et al., 2004). No correction factors were used to merge the SMPS and OPS data: $D_{\mathrm{m}}$ and $D_{\mathrm{o}}$ were both assumed to be equivalent to geometric diameter.

Knowledge of particle density is required for this conversion. This value can be estimated from bulk mass concentration measurements made, for example, by an aerosol chemical speciation monitor (ACSM) and an instrument which measures black carbon (BC), such as a multi-angle absorption spectrometer (MAAP). 
Average density $=\frac{m_{\mathrm{BC}}+m_{\mathrm{Org}}+m_{\mathrm{Cl}}+m_{\mathrm{SO}_{4}}+m_{\mathrm{NO}_{3}}+m_{\mathrm{NH}_{4}}}{\frac{m_{\mathrm{BC}}}{1.5}+\frac{m_{\mathrm{Org}}}{1.2}+\frac{m_{\mathrm{Cl}}}{1.52}+\frac{m_{\mathrm{SO}_{4}}+m_{\mathrm{NO}_{3}}+m_{\mathrm{NH}_{4}}}{1.75}}$,

where $m$ is the average mass of BC and ACSM species. 1.5, 1.2, 1.52 and 1.75 (Allan et al., 2003) are material densities for $\mathrm{BC}$, organic aerosol (Org), non-sea salt $\mathrm{Cl}^{-}, \mathrm{SO}_{4}^{2-}$, $\mathrm{NO}_{3}^{-}$and $\mathrm{NH}_{4}^{+}$respectively. An average estimated density of $1.4 \mathrm{~g} \mathrm{~cm}^{-3}$ was observed for bulk aerosol for the ADRIMED and SAF-MED campaigns. From the density calculation it is clear that neither metal-rich nor sea salt particles are taken into account. From the PILS-IC (Particle into Liquid Sampler ion chromatography) it was clear that sea salt particles constituted a significant fraction of $\mathrm{PM}_{10}$ aerosol (6\% overall, $40-50 \%$ during the major sea salt event). The average density was therefore expected to be larger, thus a density of 1.7 (Reinard et al., 2007) was used to convert the diameters.

Mass concentrations can be obtained from the scaled number concentrations by (Reinard et al., 2007):

$m=\frac{\pi}{6} \rho_{\mathrm{p}} d_{\mathrm{ve}}^{3}$.

A precise transformation of number to mass concentration requires knowledge of $\chi$ and $\rho_{\mathrm{p}}$ for each particle class. As discussed above, $\chi$ is assumed to be 1 . The use of a single density, $\rho_{\mathrm{p}}$, for ATOFMS scaling has previously resulted in satisfactory PM mass reconstruction when compared to other quantitative measurements (Healy et al., 2012, 2013; Qin et al., 2006). However, a single density assumption is known to be incorrect due to differing particle compositions (Maricq and Xu, 2004; Spencer and Prather, 2006). Different particle classes will exhibit different particle densities. A range of densities was therefore used to calculate mass concentrations for each particle class, which can be found in Table 2 . The class densities were estimated from the bulk densities of the chemical components indicated in the mass spectra as described by Bein et al. (2006) and Reinard et al. (2007).

\subsection{Correlations}

Reconstructed ATOFMS mass concentrations were then compared using regression analysis and the coefficient of determination with those obtained by the TEOM (tapering element oscillating microbalance; $\mathrm{PM}_{10}$ and $\mathrm{PM}_{1}$ mass concentrations), PILS-IC $\left(\mathrm{PM}_{10}\right.$ mass concentrations of $\mathrm{SO}_{4}^{2-}$, $\mathrm{NH}_{4}^{+}, \mathrm{NO}_{3}^{-}, \mathrm{K}^{+}, \mathrm{Ca}^{2+}, \mathrm{Na}^{+}, \mathrm{Mg}^{+}, \mathrm{Cl}^{-}$, oxalate, methanesulfonate - MSA), MAAP (BC mass concentrations) and ACSM $\left(\mathrm{PM}_{1}\right.$ mass concentrations of $\mathrm{SO}_{4}^{2-}, \mathrm{NH}_{4}^{+}, \mathrm{NO}_{3}^{-}$, $\mathrm{Cl}^{-}$, organic carbon). Positive matrix factorisation (PMF) performed on the ACSM organic fragments produces factors which correspond to a group of OA constituents with similar chemical composition and temporal behaviour that are characteristic of different sources and/or atmospheric processes (Zhang et al., 2011). Three factors were resolved: low-volatility oxygenated organic aerosol (LV-OOA, aged and non-volatile), semi-volatile oxygenated organic aerosol (SV-OOA, less oxidised and aged than LV-OOA) and hydrocarbon-like organic aerosol (HOA, representative of fossil fuel combustion). More information on ACSM results and source apportionment are available in Michoud et al. (2017).

The coefficient of determination, $R^{2}$, was used to evaluate the effectiveness of the ATOFMS mass reconstruction. All $R^{2}$ values can be found in Table $\mathrm{S} 1$ in the Supplement. This analysis was considered appropriate as the objective of ATOFMS mass reconstruction was to produce mass concentrations as similar as possible to other mass measurement techniques. $R^{2}$ values of $<0.5, \sim 0.5-0.7$ and $>0.7$ are typically considered indicative of weak, moderate and strong linear (positive or negative) relationships respectively.

\section{Results and discussion}

\subsection{Air mass back-trajectories}

Back-trajectory analysis was performed using the HYSPLIT model (Revision 631, July 2014) (Draxler and Hess, 1998) to identify air masses influencing the sampling site. The HYSPLIT model was run using PC Windows-based software available online (http://www.ready.noaa.gov/HYSPLIT.php) and meteorological input from the Global Data Assimilation System (GDAS) archive. Then $120 \mathrm{~h}$ back-trajectories ending $500 \mathrm{~m}$ above ground level (a.g.l.) at Ersa (Corsica) were calculated for each hour between 12 June and 7 August 2013 (total: 1344 trajectories). Five broad periods with different air mass regimes were identified in the period based on the ATOFMS, OPS, ACSM, $\mathrm{PM}_{1}$ and $\mathrm{PM}_{10}$ temporal profiles. Separate cluster analyses were performed to classify the trajectories for each of these five campaign periods (Fig. 1). A plot of total spatial variance as a function of the number of clusters was used to determine the number of clusters. The clustered HYSPLIT $120 \mathrm{~h}$ back-trajectories for each period were used to determine which air masses most influenced the ATOFMS measurements, and temporal profiles for particle numbers and mass concentrations have been labelled with these air mass origins (France, Mediterranean, Spain, North Atlantic, UK, Italy, eastern Europe).

Period 1 (12-20 June) was dominated by recirculating air masses over the Mediterranean Sea, Period 2 (20-26 June) by North Atlantic air masses, Period 3 (26 June-4 July) by trajectories passing largely over France, Period 4 (429 July) mostly by Mediterranean recirculations and Period 5 (29 July-7 August) by Mediterranean recirculations and continental European air masses. The sampling site was therefore influenced by long-range North Atlantic marine emissions and European emissions which were subsequently recirculated over the Mediterranean Sea, with relatively infrequent input from the Sahara. Combined with a sampling period of 8 weeks, it is clear that the site was well placed to pro- 
Period 1

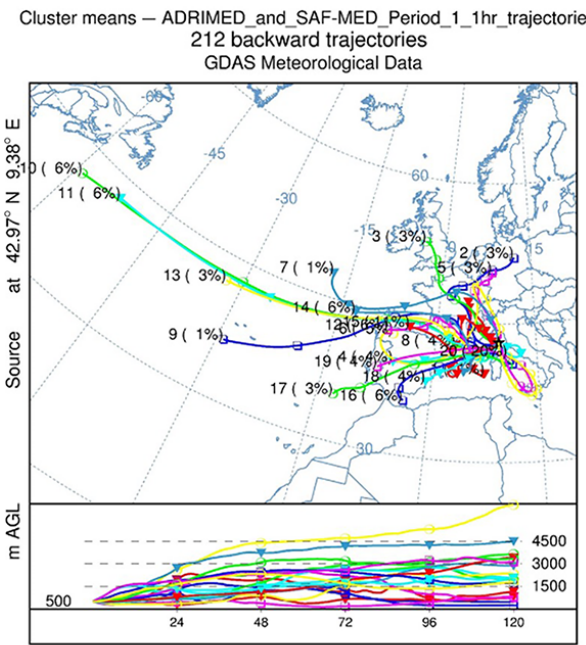

Period 3

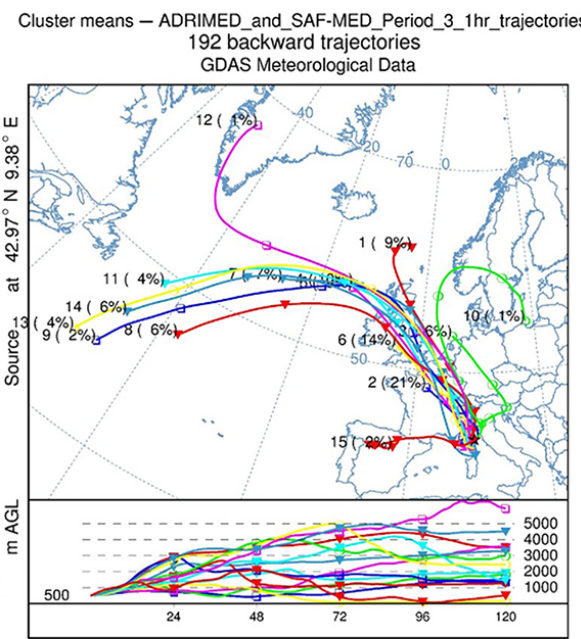

Period 2

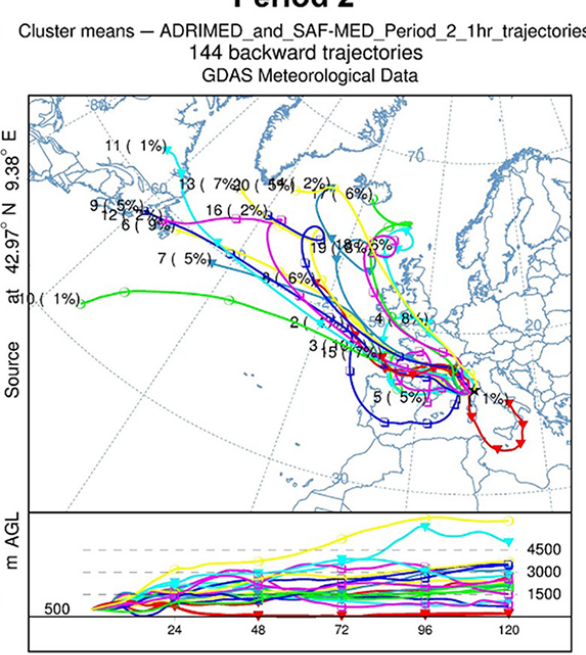

Period 4

Cluster means - ADRIMED_and_SAF-MED_Period_4_1hr_trajectories 585 backward trajectories

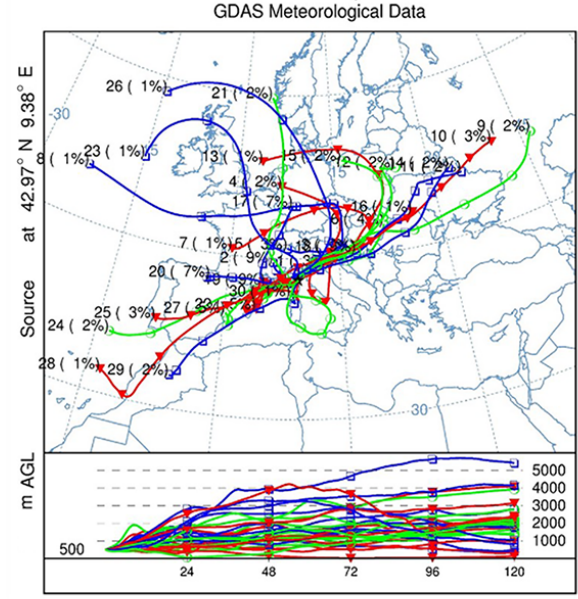

Period 5

Cluster means - ADRIMED_and_SAF-MED_Period_5_1 $\mathrm{hr}$ _trajectories 211 backward trajectories

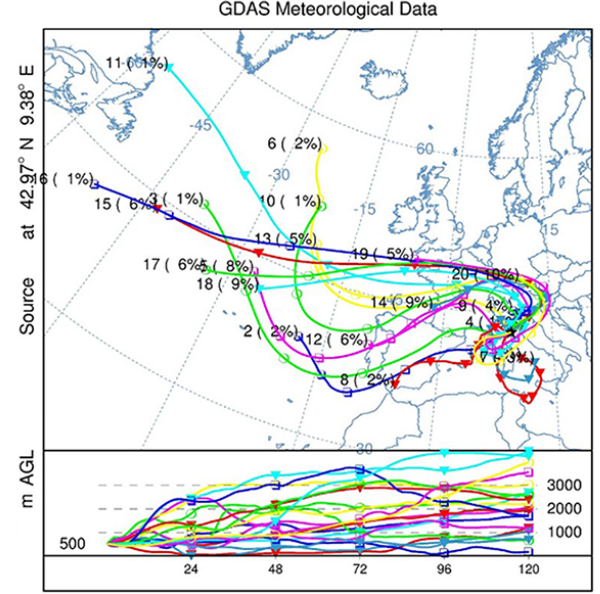

Figure 1. Cluster analysis of $120 \mathrm{~h}$ back-trajectories calculated using the HYSPLIT model, ending at Cap Corse sampling site at $500 \mathrm{~m}$ above ground level every $1 \mathrm{~h}$ for the five periods identified during ADRIMED and SAF-MED. 
Table 2. Detailed composition of ATOFMS data set during ADRIMED and SAF-MED, by particle classes.

\begin{tabular}{|c|c|c|c|c|c|c|c|c|c|}
\hline Category & $\begin{array}{l}\text { Particle } \\
\text { class }\end{array}$ & $\begin{array}{r}\text { No. of } \\
\text { particles }\end{array}$ & $\begin{array}{r}\% \text { of } \\
\text { total } \\
\text { ionised }\end{array}$ & $\begin{array}{r}\% \text { particles } \\
\text { with } \\
\text { negative } \\
\text { spectra }\end{array}$ & $\begin{array}{r}\text { No. of } \\
\text { particles } \\
\text { containing } \\
\text { Oxalate }\end{array}$ & $\begin{array}{r}\text { No. of } \\
\text { particles } \\
\text { containing } \\
\text { MSA }\end{array}$ & $\begin{array}{l}\text { Assumed } \\
\text { Density } \\
\left(\mathrm{g} \mathrm{cm}^{-3}\right)\end{array}$ & $\begin{array}{r}\% \text { of } \\
\text { total } \\
\text { ATOFMS } \\
\text { mass }\end{array}$ & $\begin{array}{r}\text { Unscaled peak } \\
\text { aerodynamic } \\
\text { diameter } \\
(\mu \mathrm{m})\end{array}$ \\
\hline \multirow[t]{8}{*}{$\mathrm{EC}$} & $\mathrm{EC}-\mathrm{SO}_{x}$ & 329555 & 28 & 3 & & & 1.4 & 22 & 0.74 \\
\hline & EC-Oxalate & 15462 & 1 & 0.5 & & & 1.4 & 1 & 0.72 \\
\hline & EC-K & 40666 & 3 & 16 & 222 & & 1.4 & 4 & 0.76 \\
\hline & $\mathrm{EC}-\mathrm{K}-\mathrm{SO}_{x}$ & 13627 & 1 & 76 & & 445 & 1.4 & 5 & 0.74 \\
\hline & EC-K-Oxalate & 23399 & 2 & 0.3 & & & 1.4 & 1 & 0.74 \\
\hline & $\mathrm{K}-\mathrm{EC}-\mathrm{NO}_{x}$ & 1391 & 0.1 & 100 & & & 1.4 & 7 & 0.74 \\
\hline & $\mathrm{K}-\mathrm{EC}-\mathrm{SO}_{x}$ & 57553 & 5 & 100 & & 191 & 1.4 & 4 & 0.85 \\
\hline & K-EC-Oxalate & 161225 & 13 & 0.3 & & & 1.4 & 7 & 0.74 \\
\hline \multirow[t]{6}{*}{ K rich } & $\mathrm{K}-\mathrm{CN}$ & 41740 & 3 & 35 & & & 1.8 & 17 & 0.76 \\
\hline & $\mathrm{K}-\mathrm{NO}_{x}$ & 12078 & 1 & 100 & 3118 & & 1.8 & 1 & 0.91 \\
\hline & $\mathrm{K}-\mathrm{SO}_{x}$ & 296512 & 25 & 9 & & 782 & 1.8 & 3 & 0.85 \\
\hline & $\mathrm{K}$-SO $x$-Oxalate & 28754 & 2 & 100 & 4988 & & 1.8 & 2 & 0.97 \\
\hline & K-Aluminosilicate & 3797 & 0.3 & 21 & 23 & & 2 & 2 & 0.91 \\
\hline & $\mathrm{K}-\mathrm{Na}$ & 2500 & 0.2 & 14 & & & 2 & 1 & 0.79 \\
\hline \multirow[t]{3}{*}{ Na rich } & Sea salt fresh & 26175 & 2 & 68 & & & 2.2 & 6 & 1.54 \\
\hline & Sea salt aged & 69566 & 6 & 59 & 270 & & 2.2 & 3 & 1.81 \\
\hline & Na-EC & 1415 & 0.1 & 100 & & & 2.2 & 3 & 0.59 \\
\hline \multirow[t]{3}{*}{ Amines } & K-TMA & 25603 & 2 & 0 & & & 1.5 & 1 & 0.74 \\
\hline & TMA-EC & 19688 & 2 & 0.3 & & & 1.5 & 1 & 0.78 \\
\hline & OC-TMA & 3734 & 0.3 & 18 & & & 1.5 & 0.5 & 0.70 \\
\hline \multirow[t]{3}{*}{ OC rich } & $\mathrm{OC}$ & 13323 & 1 & 2 & 110 & & 1.8 & 2 & 0.74 \\
\hline & $\mathrm{K}-\mathrm{OC}-\mathrm{NO}_{x}$ & 1368 & 0.1 & 100 & & & 1.8 & 0.2 & 0.66 \\
\hline & K-OC-SO $x$ & 7435 & 1 & 95 & & & 1.8 & 1 & 0.64 \\
\hline \multirow[t]{2}{*}{ V rich } & $\mathrm{V}$ & 9810 & 1 & 9 & 71 & 65 & 3.1 & 2 & 0.70 \\
\hline & $\mathrm{EC}-\mathrm{V}$ & 3827 & 0.3 & 43 & & 198 & 3.1 & 1 & 0.69 \\
\hline Fe rich & $\mathrm{Fe}$ & 2199 & 0.2 & 71 & 215 & 37 & 3.6 & 0.5 & 0.88 \\
\hline Ca rich & $\mathrm{Ca}$ & 2400 & 0.2 & 82 & 352 & 14 & 2.6 & 1 & 1.08 \\
\hline
\end{tabular}

vide an insight into the composition of Mediterranean aerosol from diverse sources under a wide variety of meteorological conditions.

\subsection{ATOFMS particle classes}

Twenty-seven distinct ATOFMS particle classes were identified and subsequently grouped into eight general categories for clarity based on the dominant marker ions: EC-rich $(53 \%$ of total mass spectra), K-rich (32\%), Na-rich (8\%), amines (4\%), OC-rich (2\%), V-rich (1\%), Fe-rich $(0.2 \%)$ and $\mathrm{Ca}$ rich $(0.2 \%)$ particles. The contribution to total particle number and mass concentration of all particle classes can be found in Table 2.

While the aerosol mixing state is varied, only a few particle classes represent the bulk of unscaled particle numbers. The dominant classes are EC-SO $\mathrm{E}_{x}, \mathrm{~K}-\mathrm{SO}_{x}$ and $\mathrm{K}-\mathrm{EC}$ Oxalate. The Na-rich category is dominated by sea-salt-aged particles, the EC-rich category by $\mathrm{EC}-\mathrm{SO}_{x}$ particles, the $\mathrm{K}$ rich category by $\mathrm{K}-\mathrm{SO}_{x}$ particles, the amines category by $\mathrm{K}$ -
TMA and EC-TMA particles, the OC-containing category by OC particles and the V-rich category by $V$ particles.

\subsection{Mass concentrations}

Reconstructed ATOFMS mass concentrations were compared with those for PM 10 , total PILS-IC species $\left(\mathrm{PM}_{10}\right)$ and $\mathrm{PM}_{1}$ (total ACSM species + BC), shown in Fig. 2. Reconstructed ATOFMS particulate mass accounted for 70-90\% of $\mathrm{PM}_{10}$ mass for most of the sampling period. Note that ATOFMS particles account for relatively little of the $\mathrm{PM}_{10}$ mass during periods when sea salt and dust are abundant, which is expected given the upper size limit $(3 \mu \mathrm{m})$ of the instrument and the low detection efficiency for supermicron particles (Cahill et al., 2014). Total ATOFMS reconstructed mass concentrations were found to correlate well with total ACSM mass concentrations $\left(R^{2}=0.71\right)$, and moderately with mass concentrations of PILS-IC SO${ }_{4}^{2-}$ and $\mathrm{NH}_{4}^{+}\left(R^{2}=\right.$ $0.58,0.44)$, the ACSM factors LV-OOA $\left(R^{2}=0.59\right)$ and SVOOA $\left(R^{2}=0.46\right), \mathrm{BC}\left(R^{2}=0.55\right)$ and $\mathrm{PM}_{1}\left(R^{2}=0.44\right)$. 


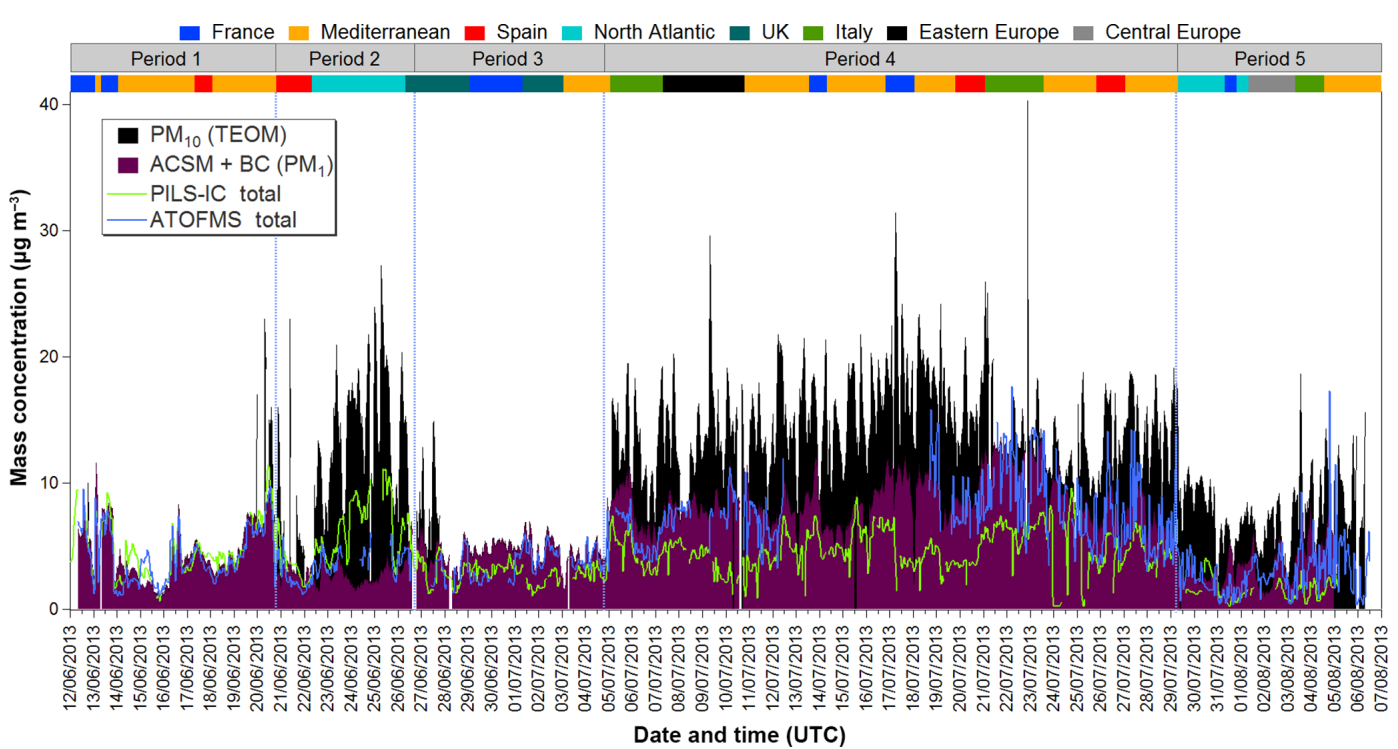

Figure 2. Hourly mass concentrations of $\mathrm{PM}_{10}$, total ACSM species + BC $\left(\mathrm{PM}_{1}\right)$, total PILS-IC species $\left(\mathrm{PM}_{10}\right)$ and total ionised ATOFMS particles during ADRIMED and SAF-MED.

ATOFMS reconstructed mass concentrations were dominated by EC-rich particles ( $52 \%)$, followed by K-rich $(25 \%)$, Na-rich $(12 \%)$, amines (3\%), OC-rich (3\%), V-rich $(3 \%)$, Ca-rich $(1 \%)$ and Fe-rich $(1 \%)$ particles. The dominance of EC and K-rich ATOFMS particles does not suggest that $\mathrm{PM}_{2.5}$ mass is comprised mostly of EC and $\mathrm{K}$. These species are simply used as markers (and for naming conventions) in ATOFMS analysis for fossil fuel and biomass combustion, while truly quantitative measurements by the PILS-IC and ACSM indicate that most of the $\mathrm{PM}_{10}$ mass was comprised of organics (36\%), sulfate (16\%) and ammonium (10\%). A detailed discussion follows in Sect. 3.4.1.

\subsection{Particle sources}

Four general sources of ATOFMS PM2.5 particles were identified during ADRIMED and SAF-MED, namely regionally transported combustion, local biomass burning, marine, and shipping. The composition of the particle classes that may have originated from these sources and comparison of their mass concentrations with other measurements are discussed in the following sections.

\subsubsection{Regionally transported combustion}

Twelve ATOFMS particles classes were identified as originating from regionally transported combustion, all found in the following three categories: EC rich, $\mathrm{K}$ rich and amines. Average mass spectra for these particles classes are shown in Fig. 3.

All of the EC-rich classes were characterised by elemental carbon fragments ions $12,24,36 \ldots \mathrm{C}^{+}$in the positive mass spectra. EC-SO $\mathrm{S}_{x}$ and EC-Oxalate did not contain detectable
${ }^{39} \mathrm{~K}^{+}$, indicating that they most likely arise from fossil fuel combustion (oil burning or traffic). EC-K, EC-K-SO $\mathrm{S}_{x}$ and EC-K-Oxalate were characterised by a stronger signal for ${ }^{36} \mathrm{C}_{3}^{+}$relative to ${ }^{39} \mathrm{~K}^{+}$. Similar particles have previously been attributed to domestic coal combustion (Healy et al., 2010), although other sources are certainly possible. K-EC$\mathrm{NO}_{x}, \mathrm{~K}-\mathrm{EC}-\mathrm{SO}_{x}$ and K-EC-Oxalate produced stronger signals for ${ }^{39} \mathrm{~K}^{+}$relative to ${ }^{36} \mathrm{C}_{3}^{+}$, a pattern usually associated with biomass burning particles. Sulfate $\left({ }^{97} \mathrm{HSO}_{4}^{-}\right)$dominated the $\mathrm{SO}_{x}$ classes, but was also present to a lesser extent in the other six EC-rich classes. Despite the average spectra for the EC-rich classes showing large signals for sulfate and nitrate $\left({ }^{46} \mathrm{NO}_{2}^{-},{ }^{62} \mathrm{NO}_{3}^{-}\right)$, most of the particles in these classes produced no negative ion spectra or only weak negative ion signals. It is therefore not possible to definitively describe their anion mixing state; however certain conclusions can still be drawn from their temporal profiles. Less nitrate, or weaker signals for these species, relative to sulfate was expected given the high ambient temperatures. Nitrate is usually mixed with EC in the form of ammonium nitrate, which is more volatile than ammonium sulfate (Querol et al., 2009; Sciare et al., 2008). A smaller signal for $\mathrm{MSA},{ }^{95} \mathrm{CH}_{3} \mathrm{SO}_{3}^{-}$ (Neubauer et al., 1997) relative to sulfate was found in the K$\mathrm{EC}_{-} \mathrm{SO}_{x}$ class, indicating processing with marine emissions (Gaston et al., 2010). The oxalate classes are characterised by their signal at $m / z-89$, a marker for deprotonated oxalic acid (Yang et al., 2009) and aged aerosol. Very small signals for ammonium $\left({ }^{18} \mathrm{NH}_{4}^{+}\right)$, not marked in the mass spectra, were found in all classes with the exception of the ECOxalate class.

The positive ion mass spectra for $\mathrm{K}-\mathrm{CN}$ and $\mathrm{K}-\mathrm{SO}_{x}$ particles are exclusively dominated by ${ }^{39} \mathrm{~K}^{+}$, typical of biomass 

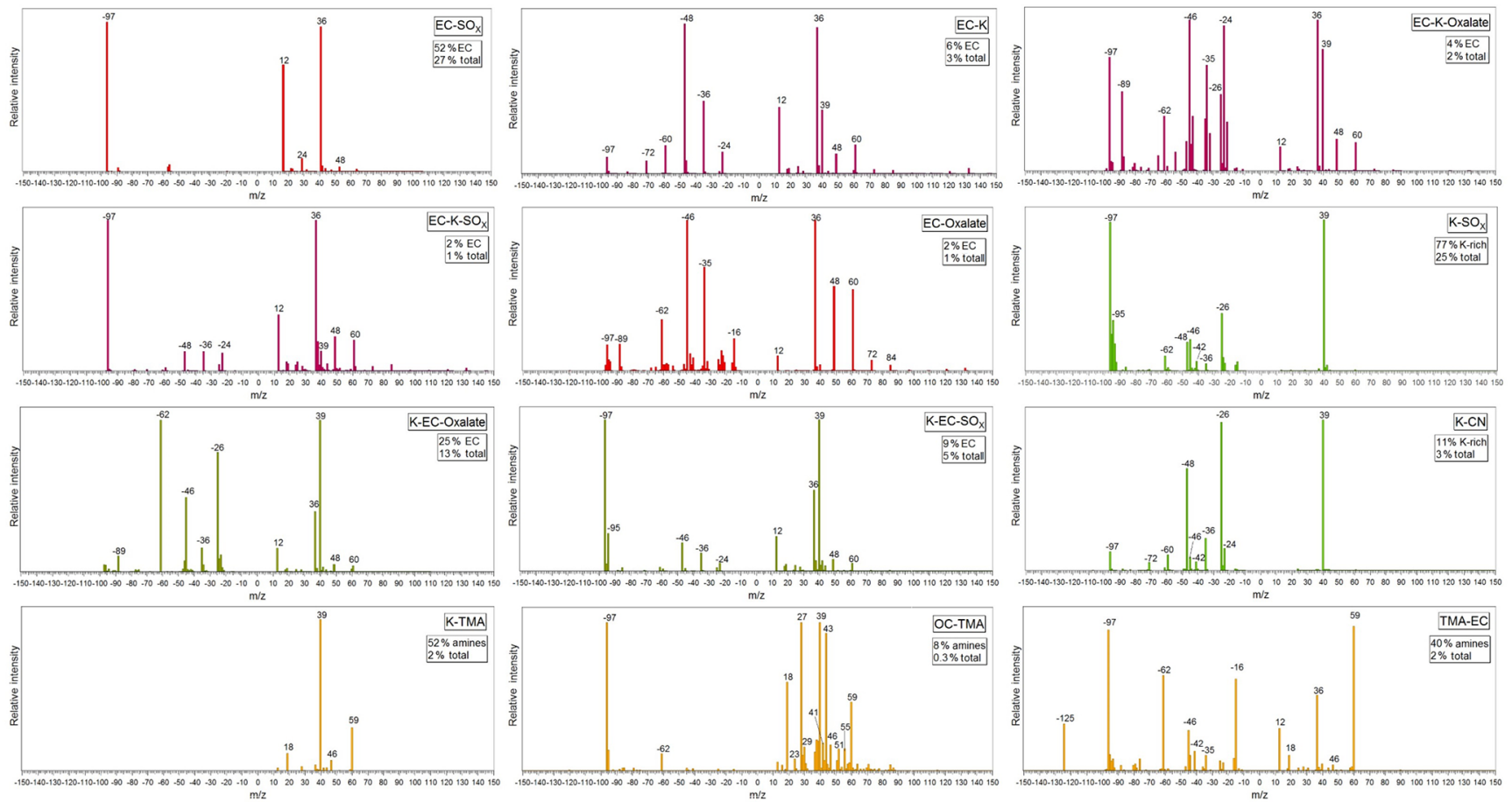

Figure 3. Average mass spectra of ATOFMS particle classes originating from regionally transported combustion sources during ADRIMED and SAF-MED. Percentages refer to a fraction of ATOFMS category and total particle numbers.

burning particles detected by ATOFMS (Lea-Langton et al., 2015; Pratt et al., 2010; Qin and Prather, 2006; Silva et al., 1999). Sulfate $\left({ }^{97} \mathrm{HSO}_{4}^{-}\right)$dominates the negative ion mass spectra of the $\mathrm{K}_{-} \mathrm{SO}_{x}$ particles, with additional signals for MSA $\left({ }^{95} \mathrm{CH}_{3} \mathrm{SO}_{3}^{-}\right)$and oxalate $\left({ }^{89}(\mathrm{COO})_{2} \mathrm{H}^{-}\right) .{ }^{26} \mathrm{CN}^{-}$. Internally mixed carbon and nitrogen, probably in the form of nitrogen-containing organic compounds (Silva et al., 1999), dominates the negative ion mass spectra of K-CN particles. EC fragments were found in all K-rich negative ion mass spectra, indicating a biomass combustion source.

Trimethylamine (TMA, ${ }^{59}\left(\mathrm{CH}_{3}\right)_{3} \mathrm{~N}^{+}$) was the most abundant alkylamine marker ion in the three amine particle classes. Also present in all three classes was a marker ion for protonated dimethylamine (DMA, $\left.{ }^{46}\left(\mathrm{CH}_{3}\right)_{2} \mathrm{NH}_{2}^{+}\right)$. A comparison of ATOFMS data sets obtained in Cork, Paris, Zurich, Dunkirk and Corsica (ADRIMED and SAF-MED) found this ion only in the latter two data sets (Healy et al., 2015). Ammonium $\left({ }^{18} \mathrm{NH}_{4}^{+}\right)$was also found in all three amine classes. The K-TMA class was dominated by ${ }^{39} \mathrm{~K}^{+}$, indicative of biomass burning, while EC-TMA particles produced ${ }^{12,36} \mathrm{C}^{+}$signals, indicating fossil fuel combustion origins. OC-TMA particles are characterised by strong ${ }^{39,41} \mathrm{~K}^{+}$, OC $\left({ }^{27} \mathrm{C}_{2} \mathrm{H}_{3}^{+}\right)$and oxidised $\mathrm{OC}\left({ }^{43} \mathrm{C}_{2} \mathrm{H}_{3} \mathrm{O}^{+}\right)$signals, suggesting biomass burning sources and atmospheric processing during transport to the site. Sulfate $\left({ }^{97} \mathrm{HSO}_{4}^{-}\right)$and nitrate $\left({ }^{46} \mathrm{NO}_{2},{ }^{62} \mathrm{NO}_{3},{ }^{125} \mathrm{H}\left(\mathrm{NO}_{3}\right)_{2}^{-}\right)$were found in the average negative mass spectra of EC-TMA and OC-TMA; however only 0.3 and $18 \%$ of these particles actually produced negative mass spectra and K-TMA particles produced none. Alkylaminium sulfate particles have been shown to readily absorb water at low relative humidities $(<45 \%)$ (Chan and Chan, 2013; Hu et al., 2014), and particle-bound water has been shown to suppress negative ion formation in mass spectrometers (Neubauer et al., 1997, 1998). The proportion of amine particles with negative mass spectra is low in contrast to other particle classes which produced signals in up to $100 \%$ of their negative mass spectra $\left(\mathrm{K}-\mathrm{EC}-\mathrm{SO}_{x}, \mathrm{~K}-\mathrm{SO}_{x}\right.$ Oxalate). This suggests particle-bound water could have had a significant effect on negative ion formation for these particles. The average negative mass spectra should therefore not be considered representative of every particle in these classes. Healy et al. (2015) previously assigned $m / z-95$ in amine-containing particles from this data set to MSA. However, closer inspection of individual spectra suggests that at least some of the signal at -95 arises from miscalibrated negative ion mass spectra, and is in fact associated with sulfate. Although $m / z-95$ cannot therefore be definitively assigned to MSA here, internal mixing of MSA and TMA is possible, as indicated by laboratory studies (Chen et al., 2015a, b). Furthermore, MSA was also measured in bulk $\mathrm{PM}_{10}$ during this campaign using the PILS-IC instrument, and is thus inevitably contained in a fraction of particles at this location.

Temporal profiles for hourly summed particle numbers for the regionally transported combustion classes are shown in Fig. 4. There are three general temporal profiles: those of $\mathrm{EC}-S O_{x}, \mathrm{EC}-\mathrm{K}-\mathrm{SO}_{x}, \mathrm{EC}-\mathrm{K}$ and EC-Oxalate, those of K- 


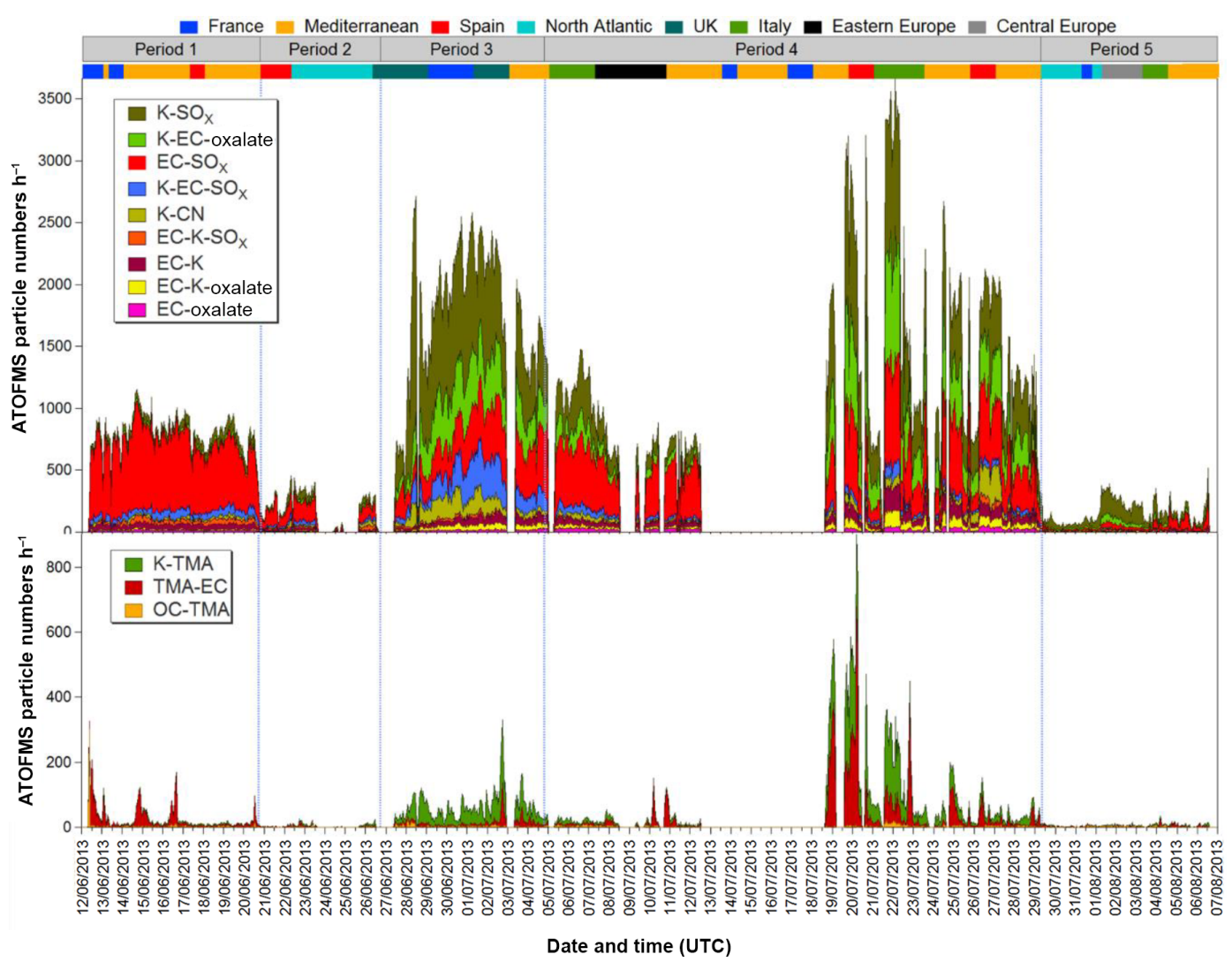

Figure 4. Time series (stacked) of hourly unscaled particle numbers for ATOFMS EC and major K-rich particle classes (top) and amine classes (bottom) observed during ADRIMED and SAF-MED. Dates are dd/mm/yyyy.

$\mathrm{SO}_{x}, \mathrm{~K}-\mathrm{EC}-\mathrm{SO}_{x}, \mathrm{~K}-\mathrm{CN}$ and K-EC-Oxalate, and finally those containing TMA. The EC-rich particle classes dominated Period 1 and were considered markers for fossil fuel combustion because most of these did not contain detectable ${ }^{39} \mathrm{~K}^{+}$. Their particle numbers remained relatively similar throughout the campaigns. For the first half of Period 1 regional air masses passed over industrialised parts of France (Marseille) and northern Italy (Po Valley) before reaching the site, while during the latter half of this period these air masses were then recirculated over the western Mediterranean (Fig. S1 in the Supplement shows the air mass back-trajectories calculated for this period using the HYSPLIT model).

Particle numbers for all EC-rich and major K-rich classes decreased noticeably during Periods 2 and 5, which were influenced by synoptic-scale air masses from the North Atlantic, effectively removing aerosol accumulated during the previous periods. On the other hand, K-rich particles, markers for biomass combustion, dominated Periods 3 and 4 . Fires were detected by MODIS (Fig. 5) over northern Italy, Ukraine and Russia throughout the sampling period and the site was heavily influenced by air masses passing over this region (Fig. 1), which could explain the constant presence of K-rich particles in the background aerosol. The increase in these particles during Period 3 may be explained by longer residence times of air masses over southern France and northern Italy relative to Period 1 , and particle numbers then began to decrease when trajectories from the North Atlantic and UK arrived at the end of Period 3.

A significant increase in fires was detected around the Black Sea from 10 July until the end of the sampling period (Fig. 5). The burning of wheat residuals has been previously documented in the eastern Mediterranean and it contributed at least $30 \%$ of EC and OC measured during similar time periods between 2001 and 2006 (Sciare et al., 2008). For $\sim 4$ days during Period 4 , air masses from over the Black Sea and eastern Europe influenced the site, followed by extensive stagnation and recirculation of that air over the western Mediterranean. These observations coincided with a further increase in K-rich particle numbers relative to Period 3.

As shown in Fig. 4, the three amine particles classes, KTMA, EC-TMA and OC-TMA, presented similar temporal profiles in Period 4 to those of major EC-rich and K-rich particles classes. Numbers of K-TMA and EC-TMA particles peaked during Period 4, while K-TMA particles dominated over EC-TMA particles during Period 3, as was the case for the major K-rich and EC-rich classes. The dominant amine class, K-TMA, correlated well with two major classes, K- 


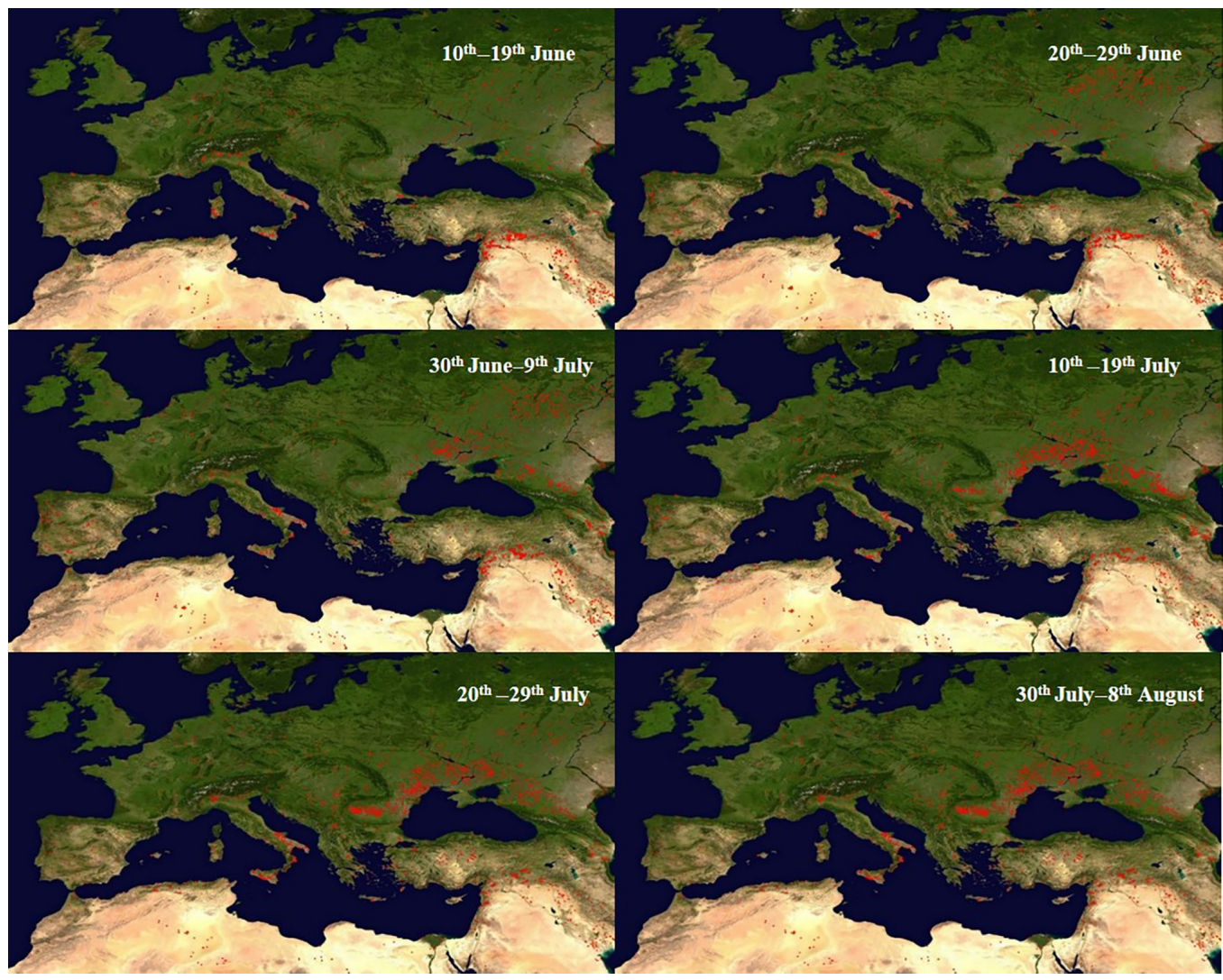

Figure 5. Locations of fires detected by the MODIS sensor on board the Terra and Aqua satellites over 10-day periods during ADRIMED and SAF-MED. Each red dot indicates a location where at least one fire was detected (http://lance-modis.eosdis.nasa.gov/cgi-bin/imagery/ firemaps.cgi).

$\mathrm{SO}_{x}$ and K-EC-Oxalate, particularly during Period $4\left(R^{2}\right.$ is 0.76 and 0.70 respectively).

Partitioning of alkylamines from the gas phase to particles has been found to be enhanced during periods of high relative humidity or fog events, with uptake increasing with aerosol acidity (Rehbein et al., 2011). No association between any of the amine classes and local relative humidity was found in this case, suggesting that this effect is not relevant close to the site but may have played a role close to the point of emission or during transport of the amine particles to the site. It also provides further evidence that the amine particles were not formed in the local environment.

To investigate how the dominant ATOFMS particle categories (EC and $\mathrm{K}$ rich) compared with the dominant bulk $\mathrm{PM}_{10}$ (excluding sea salt) species, hourly mass concentrations of $\mathrm{PM}_{10}, \mathrm{BC}, \mathrm{ACSM}$ species $\left(\mathrm{SO}_{4}^{2-}, \mathrm{NH}_{4}^{+}\right.$and $\mathrm{SV}$ OOA) and reconstructed mass concentrations for ATOFMS EC-rich and K-rich particle categories (combined particle classes) were plotted (Fig. 6). EC and K-rich mass concentrations have been stacked to compare their values with the contributions from $\mathrm{BC}, \mathrm{SV}-\mathrm{OOA}, \mathrm{LV}-\mathrm{OOA}, \mathrm{SO}_{4}^{2-}$ and $\mathrm{NH}_{4}^{+}$(also stacked). For the full sampling period, reconstructed mass concentrations of all ATOFMS EC-rich parti- cle classes correlated well with ACSM SO $\mathrm{SO}_{4}^{2-}\left(R^{2}=0.61\right)$, $\mathrm{NH}_{4}^{+}\left(R^{2}=0.62\right)$, the LV-OOA factor $\left(R^{2}=0.59\right)$ mass concentrations (which accounted for the largest proportion of organics mass, $\sim 54 \%$ ) and OPS (for the channel 0.3$0.579 \mu \mathrm{m})$ number concentrations $\left(R^{2}=0.69\right)$ and moderately with $\mathrm{PM}_{1}\left(R^{2}=0.46\right)$ and $\mathrm{BC}\left(R^{2}=0.50\right)$ mass concentrations. Reconstructed mass concentrations for all Krich classes (including local combustion) correlated with the same species but only moderately ( $R^{2}$ ranged from 0.3 to $0.5)$. Individual particle classes did not produce stronger correlations, suggesting that no single class was an important contributor of $\mathrm{PM}_{2.5}$ composition.

The average mass spectra of ATOFMS EC and K-rich classes showed that sulfate, nitrate, oxalate and MSA were present. From the PILS-IC and ACSM measurements it was clear that the dominant secondary inorganic ions were sulfate $\left(19 \%\right.$ of $\mathrm{PM}_{1}, 16 \%$ of $\left.\mathrm{PM}_{10}\right)$ and ammonium $(10 \%$ of $\mathrm{PM}_{1}, 10 \%$ of $\mathrm{PM}_{10}$ ), with nitrate contributing relatively little to both $\mathrm{PM}_{1}(4 \%)$ and $\mathrm{PM}_{10}(4 \%)$ mass. $\mathrm{K}^{+}$, oxalate and MSA contributed less again to $\mathrm{PM}_{10}(0.4,0.1$ and $0.2 \%$ respectively). $\mathrm{K}^{+}$is readily ionised by the ATOFMS desorption/ionisation laser so its prevalence in ATOFMS particles 


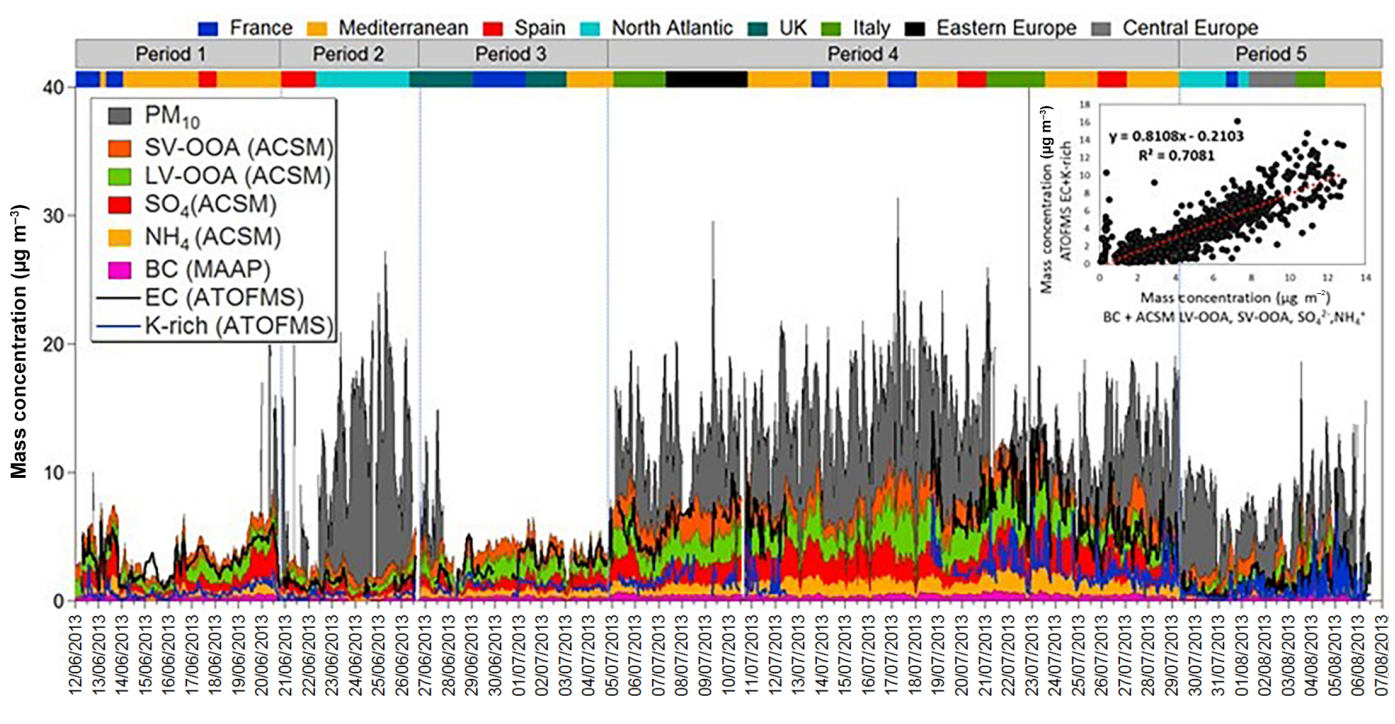

Date and time (UTC)

Figure 6. Hourly mass concentrations of $\mathrm{PM}_{10}$, ACSM species $\left(\mathrm{SO}_{4}^{2-}, \mathrm{NH}_{4}^{+}\right.$, organic aerosol factors SV-OOA and LV-OOA), $\mathrm{BC}$ and reconstructed ATOFMS EC and K-rich particles. BC and ACSM species profiles are stacked, as are both ATOFMS categories, but separately. This compares the ATOFMS mass concentrations with BC + ACSM species. Inset is a scatter plot of mass concentrations of ATOFMS $\mathrm{EC}$-rich $+\mathrm{K}$-rich particles compared with those for $\mathrm{BC}+\mathrm{SV}-\mathrm{OOA}+\mathrm{LV}-\mathrm{OOA}+\mathrm{SO}_{4}^{2-}+\mathrm{NH}_{4}^{+}$. Dates are dd/mm/yyyy.

is not necessarily representative of its mass concentration (Gross et al., 2000a).

The high level of agreement between mass concentrations of EC-rich $+\mathrm{K}$-rich particles and $\mathrm{BC}+\mathrm{SV}-\mathrm{OOA}+\mathrm{LV}$ $\mathrm{OOA}+\mathrm{SO}_{4}^{2-}+\mathrm{NH}_{4}^{+}$is shown in a scatter plot in Fig. 6. It suggests that those particles were comprised of LV-OOA to a considerable degree, consistent with the ageing of the aerosol particles during regional transport, and of SV-OOA, which suggests interaction with locally formed organic aerosol; details of organic aerosol formation and sources during the campaigns can be found in Michoud et al. (2017). However, no significant OC signals were found in any of the EC-rich or K-rich classes. Particles which did produce strong signals for OC ions contributed relatively little to total ATOFMS particle numbers. Similarly to ${ }^{39} \mathrm{~K}^{+}$, the ATOFMS favours ionisation of EC over OC (Ferge et al., 2006; Silva and Prather, 2000), which results in weak signals for OC in particles which also contain $\mathrm{EC}$ or $\mathrm{K}^{+}$. This may account for the underrepresentation of organic aerosol in the ATOFMS measurements.

\subsubsection{Local biomass burning}

The sampling site on Corsica was chosen for its negligible local anthropogenic sources relative to the regional background. However, a few local sources did influence the site, though these did not contribute significantly to particle number or mass concentrations. Local combustion events were detected in the form of $\mathrm{K}^{-\mathrm{NO}_{x}}, \mathrm{~K}-\mathrm{OC}-\mathrm{NO}_{x}$, and $\mathrm{K}-\mathrm{OC}-\mathrm{SO}_{x}$ particles, and distinguished themselves from the dominating regional aerosol by occurring mostly during Periods 1 and 2 over 5-7 h events (Fig. 7). The first event was observed on
12 June from 13:00 to 18:00 UTC and its source as biomass burning (in the form of vegetation trimmings) was visually confirmed on the north-eastern slopes of the site.

The composition of these particles is consistent with this observation: $\mathrm{K}^{+}$is a common marker for biomass combustion, which typically also produces organic aerosol (Pagels et al., 2013; Silva et al., 1999). Average mass spectra for local biomass burning particles are shown in Fig. 8. Nitrate $\left({ }^{46} \mathrm{NO}_{2}^{-},{ }^{62} \mathrm{NO}_{3}^{-}\right)$dominated the negative mass spectra of $\mathrm{K}^{-\mathrm{NO}_{x}}$ particles, but they also contained sulfate $\left({ }^{97} \mathrm{HSO}_{4}^{-}\right)$, nitrogen-containing organic compounds $\left({ }^{26} \mathrm{CN}^{-}\right)$, EC $\left(24,36,48 \mathrm{C}^{-}\right)$and oxygen $\left({ }^{16} \mathrm{O}^{-}\right) . \mathrm{K}-\mathrm{OC}-\mathrm{NO}_{x}$ and $\mathrm{K}-\mathrm{OC}-\mathrm{SO}_{x}$ are characterised by a large signal for ${ }^{39} \mathrm{~K}^{+}$ (confirmed by the prominent signal for the ${ }^{41} \mathrm{~K}^{+}$isotope), hydrocarbon fragments $\left({ }^{27} \mathrm{C}_{2} \mathrm{H}_{3}^{+},{ }^{29} \mathrm{C}_{2} \mathrm{H}_{5}^{+},{ }^{51} \mathrm{C}_{4} \mathrm{H}_{3}^{+},{ }^{63} \mathrm{C}_{5} \mathrm{H}_{3}^{+}\right)$ in the positive mode and strong signals for ${ }^{43} \mathrm{C}_{2} \mathrm{H}_{3} \mathrm{O}^{+}$, a marker for oxidised organic aerosol (Silva and Prather, 2000). Sulfate was found in both OC-rich classes, but dominated the negative mass spectra of $\mathrm{K}-\mathrm{OC}-\mathrm{SO}_{x}$ particles. $\mathrm{K}$ OC-SO $x$ particles also exhibited a small MSA $\left({ }^{95} \mathrm{CH}_{3} \mathrm{SO}_{3}^{-}\right)$ signal, indicating at least some mixing with marine biogenic emissions prior to detection. Nitrate dominated the K-OC$\mathrm{NO}_{x}$ class and was also present to a lesser extent in the $\mathrm{K}$ $\mathrm{OC}^{-\mathrm{SO}_{x}}$ classes.

Garden waste biomass was frequently burned in the surrounding villages during June; such combustion was prohibited from July onwards which explains the lack of similar local events. No local wildfires or controlled agricultural burning was noted during the sampling period. Between 27 June and 1 July, $\mathrm{K}^{-\mathrm{NO}_{x}}, \mathrm{~K}-\mathrm{EC}-\mathrm{NO}_{x}$ and possibly K-OC-SO${ }_{x}$ 


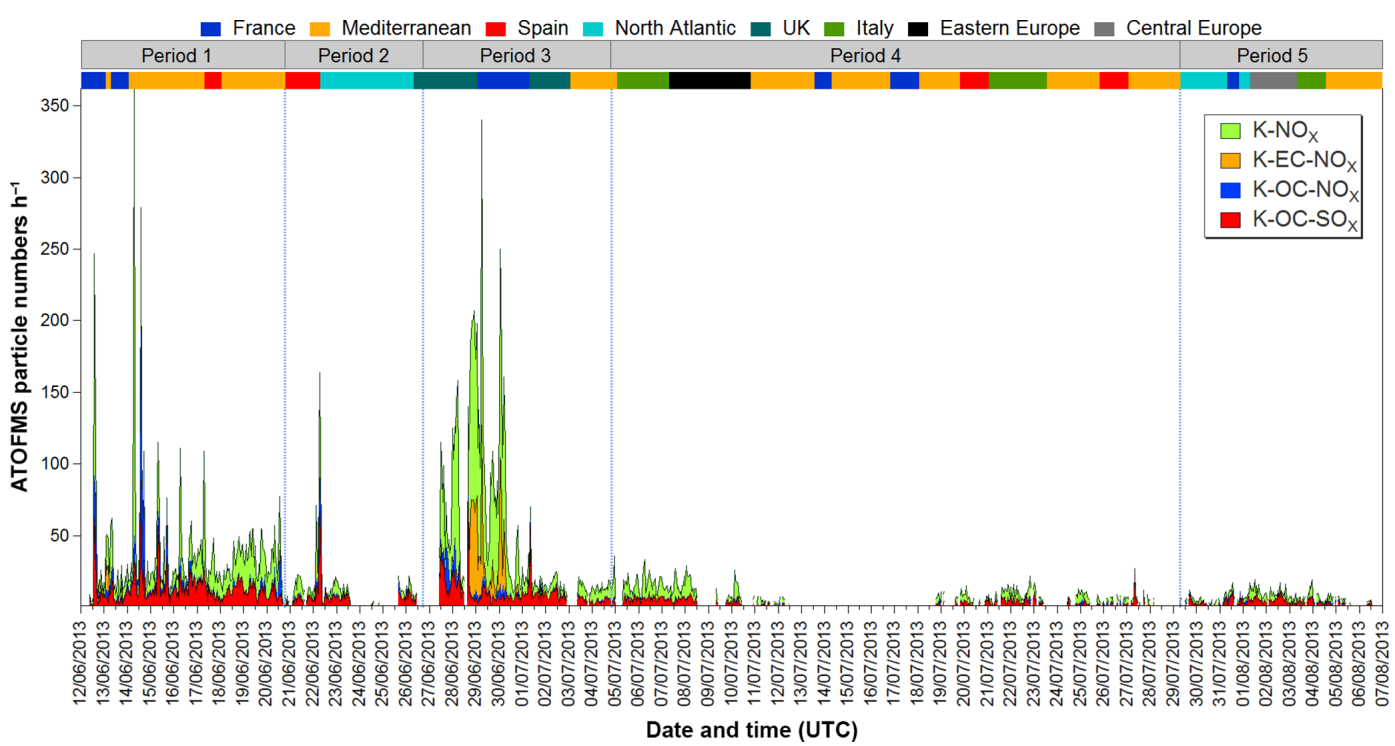

Figure 7. Time series of hourly unscaled particle numbers for ATOFMS particle classes associated with local biomass burning observed during ADRIMED and SAF-MED. Dates are dd/mm/yyyy.

were of regional biomass burning origin, because their temporality was noticeably different to the preceding short local events; this period was influenced by short-range air masses residing over southern France and northern Italy. Peak aerodynamic diameters for these particles were also larger during this period compared to previous local combustion events: $700-900 \mathrm{~nm}\left(D_{\mathrm{a}}\right)$ versus $300-500 \mathrm{~nm}$. This represents a significant amount of growth through ageing, assuming these particles were of a similar size at their point of origin to those burned locally in Corsica. $\mathrm{K}^{-\mathrm{NO}_{x}}$ and $\mathrm{K}-\mathrm{OC}-\mathrm{SO}_{x}$ particles were also present throughout both campaigns in low numbers outside of events, indicating persistent regional sources.

\subsubsection{Sea salt}

ATOFMS sea salt particles were separated into two classes, fresh and aged. Their composition and comparison with other sea salt measurements (e.g. $\mathrm{Na}$ and $\mathrm{Cl}$ mass concentrations from PILS-IC) are the subject of a detailed study of primary marine aerosols during ADRIMED (Claeys et al., 2016), so will only be discussed briefly here.

Both sea salt classes are typical of those observed in other coastal/marine environments (Gard et al., 1998; Dall'Osto et al., 2004; Healy et al., 2010). Average mass spectra are shown in Fig. 8. The positive modes for both fresh and aged particles are similar and are characterised by sodium ions $\left({ }^{23} \mathrm{Na}^{+},{ }^{46} \mathrm{Na}_{2}^{+},{ }^{62} \mathrm{Na}_{2} \mathrm{O}^{+},{ }^{63} \mathrm{Na}_{2} \mathrm{OH}^{+}\right.$and $\left.{ }^{81,83} \mathrm{Na}_{2} \mathrm{Cl}^{+}\right)$and ${ }^{39} \mathrm{~K}^{+}$. Fresh and aged sea salt particles were differentiated by their negative mass spectra, which showed peaks for ${ }^{16} \mathrm{O}^{-}$, ${ }^{35,37} \mathrm{Cl}^{-}$, nitrate $\left({ }^{46} \mathrm{NO}_{2}^{-},{ }^{62} \mathrm{NO}_{3}^{-}\right)$and ${ }^{93,95} \mathrm{NaCl}_{2}^{-}$for fresh sea salt particles, while the signals for nitrate dominate the aged sea salt negative mode and sodium chloride adducts are virtually absent. The absence of $\mathrm{NaCl}$ ions and strong ni- trate signals indicates extensive replacement of $\mathrm{Cl}^{-}$by $\mathrm{NO}_{3}^{-}$ (Gard et al., 1998), while the presence of nitrate in the negative mass spectra of the fresh sea salt particles suggests that these are not truly fresh but have also undergone some $\mathrm{Cl}$ replacement.

Temporal profiles for ATOFMS sea salt particle numbers, OPS number concentrations, PILS-IC sea salt aerosol (SSA, calculated using SSA $=\left[\mathrm{Cl}^{-}\right]+\left[\mathrm{Na}^{+}\right] \times 1.47$; Bates et al., 2012) and ATOFMS fresh sea salt mass concentrations are shown in Fig. 9. The two ATOFMS sea salt classes presented noticeably different temporal profiles. Aged sea salt was consistently present in the background throughout both campaigns, while fresh sea salt was detected mostly during short periods (20-26 June, 30 July). This coincided with increases in OPS number concentrations in the 0.579-2.156 $\mu \mathrm{m}$ range and PILS-IC SSA. Correlation between ATOFMS fresh sea salt mass and SSA is particularly strong $\left(R^{2}=0.81\right)$ for the sea salt event during Period 2. Reconstructed mass concentrations for fresh sea salt particles accounted for $50-80 \%$ of SSA during the main event. This and a strong correlation between ATOFMS fresh sea salt mass concentrations and $0.579-2.156 \mu \mathrm{m}$ particles $\left(R^{2}=0.81\right)$ suggests a significant amount of fresh sea salt was in the $\mathrm{PM}_{2.5}$ fraction; an estimated $30 \%$ of $\mathrm{PM}_{10}$ SSA mass was accounted for by $\mathrm{PM}_{2.5}$ ATOFMS fresh sea salt during the 5-day event in Period 2.

\subsubsection{Mineral dust}

Three prominent mineral dust events were characterised by increases in $\mathrm{Ca}^{2+}$ mass concentrations and 2.156-8.032 $\mu \mathrm{m}$ particle number concentrations during 12-13 June, 1719 June and 23-26 June (Fig. 9). The third event coincided with the main sea salt event and was also distinguished by 

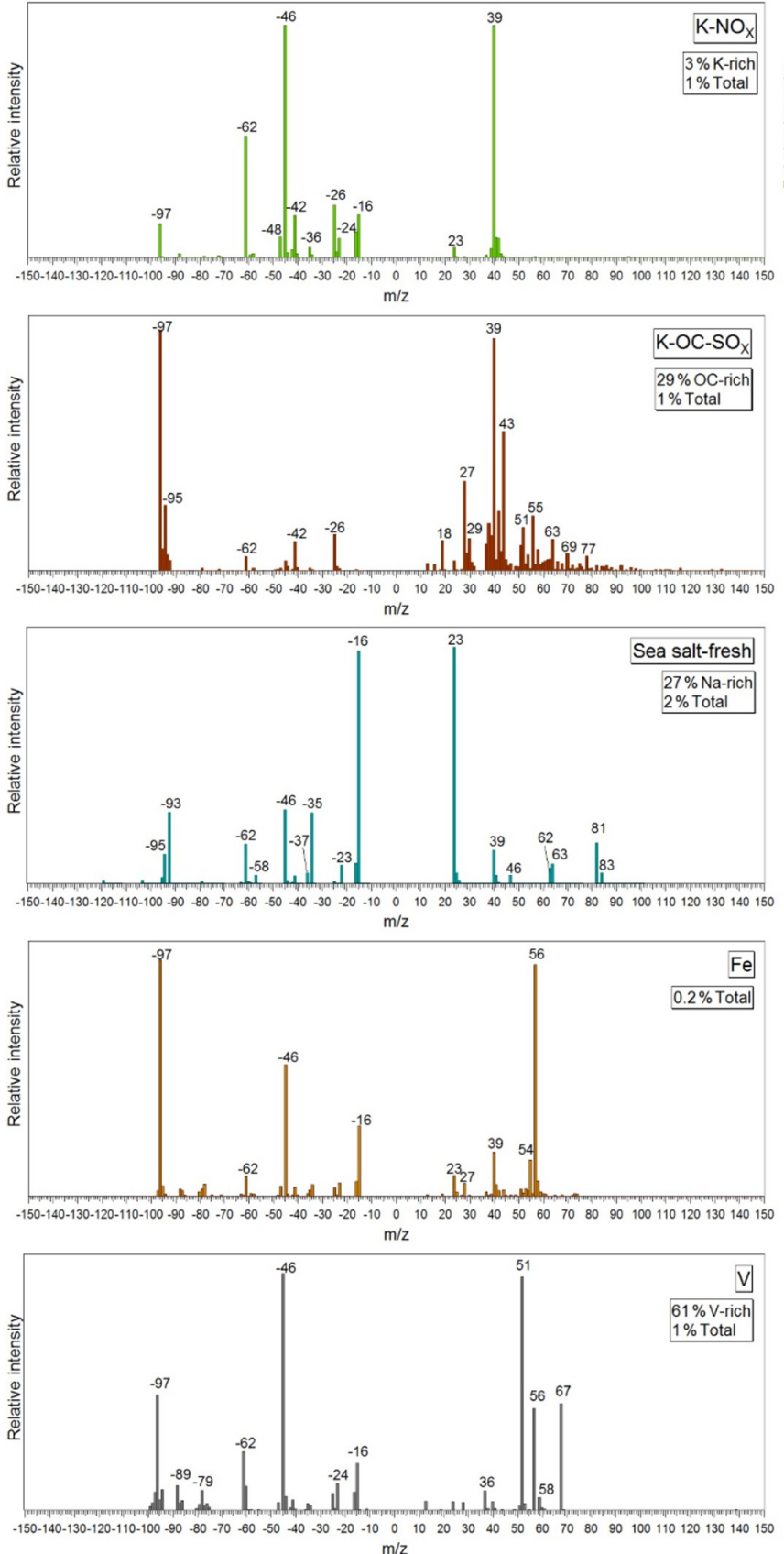
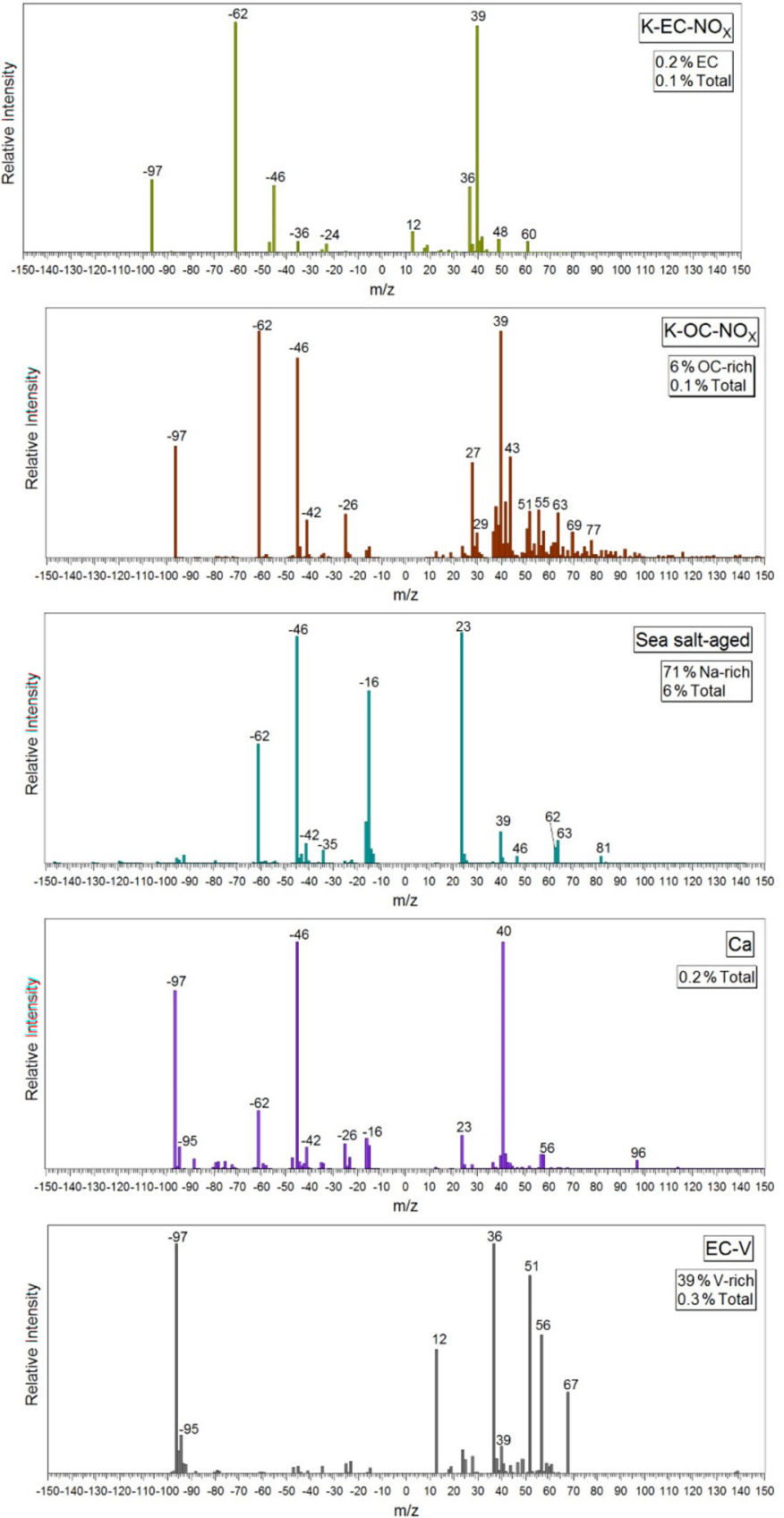

Figure 8. Average mass spectra for ATOFMS particle classes from local biomass burning, marine, dust and shipping sources during ADRIMED and SAF-MED.

contributions of $\mathrm{K}^{+}$. The 17-19 June event is likely related to a moderate African dust event that passed over Corsica, as shown by MSG/SEVIRI aerosol optical depth (Fig. S2). The two other periods appear due to local dust. Two particle classes were identified as potential mineral dust by the ATOFMS, Fe and Ca. Average mass spectra are shown in Fig. 8. Fe and $\mathrm{Ca}$, along with $\mathrm{Al}$ and aluminosilicates, are typical dust tracers which produce ions detectable by
ATOFMS (Guazzotti et al., 2001; Silva et al., 2000; Sullivan et al., 2007). K-rich dust is also a possibility.

The $\mathrm{Fe}$ particles detected in Corsica were internally mixed with ${ }^{39} \mathrm{~K}^{+},{ }^{23} \mathrm{Na}^{+},{ }^{27} \mathrm{Al}^{+}$, sulfate $\left({ }^{97} \mathrm{HSO}_{4}^{-}\right)$and nitrate, although only a weak signal for ${ }^{27} \mathrm{Al}^{+}$and no aluminosilicate signals (e.g. ${ }^{43} \mathrm{AlO}^{-},{ }^{59} \mathrm{AlO}_{2}^{-},{ }^{60} \mathrm{SiO}_{2}^{-},{ }^{76} \mathrm{SiO}_{3}^{-},{ }^{77} \mathrm{HSiO}_{3}^{-}$, ${ }^{103} \mathrm{AlSiO}_{3}^{-}$) were found, which could also suggest industrial origins (Corbin et al., 2012; Dall'Osto et al., 2008; Zhang et al., 2009). Ca particles are dominated by ${ }^{40} \mathrm{Ca}^{+}$, with weaker 


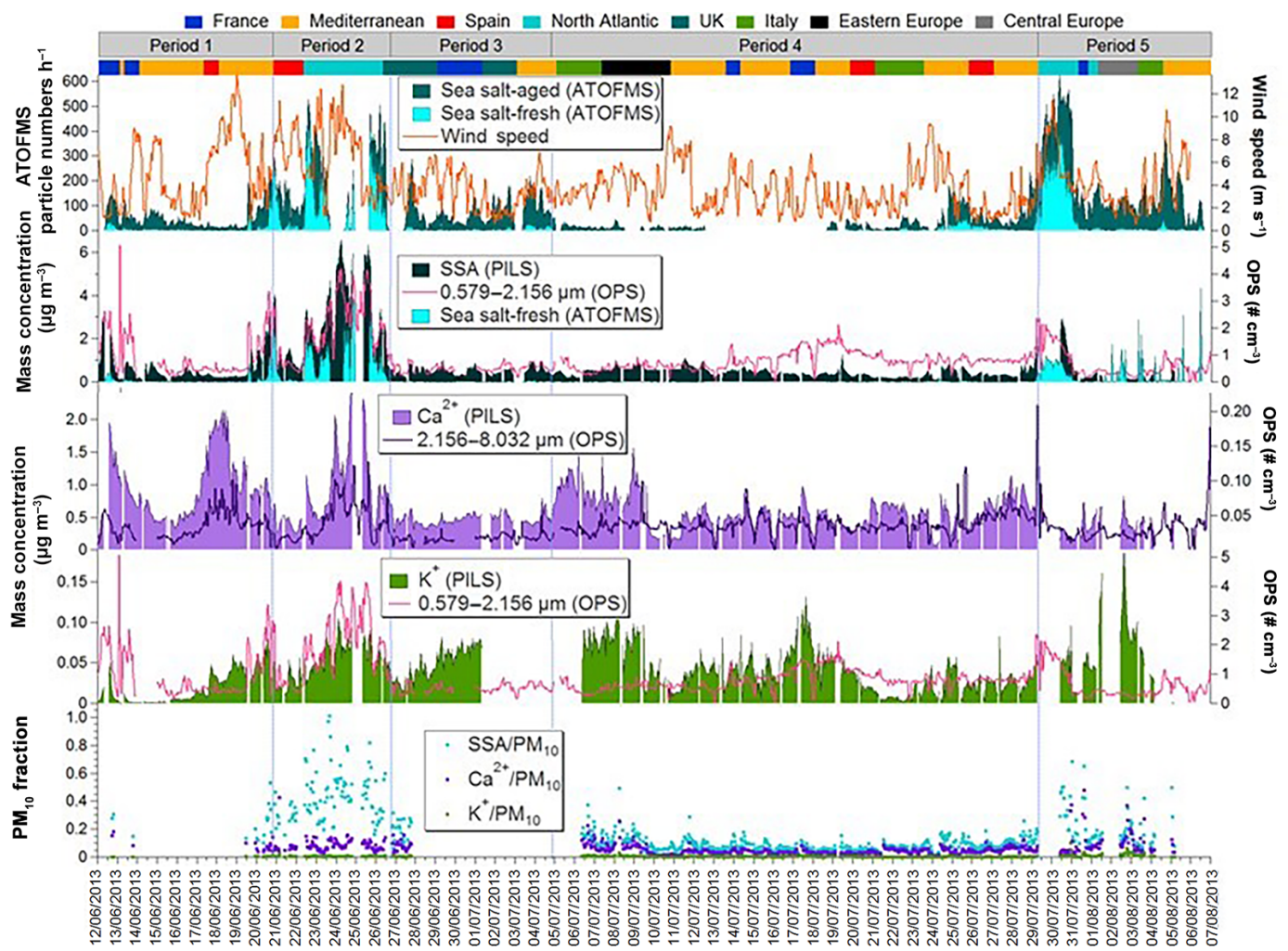

Date and time (UTC)

Figure 9. Time series of hourly ATOFMS sea salt particle numbers, OPS number concentrations, PILS-IC SSA (sea salt aerosol), Ca ${ }^{+}, \mathrm{K}^{+}$ and ATOFMS fresh sea salt mass concentrations, and $\mathrm{PM}_{10}$ fractions observed during ADRIMED and SAF-MED. Dates are dd/mm/yyyy.

signals for ${ }^{56} \mathrm{CaO}^{+}$and ${ }^{96} \mathrm{Ca}_{2} \mathrm{O}^{+} .34 \%$ of all $\mathrm{Ca}$ particles produced positive EC ions, which suggests a vehicular traffic source (Gross et al., 2000b; Silva and Prather, 1997; Song et al., 2001) to and from the site and from a few local villages in which tourist population increases during the summer.

The $\mathrm{Fe}$ and $\mathrm{Ca}$ classes only contributed a small number of particles $(0.2 \%$ each $)$ relative to the total number ionised by the ATOFMS and no agreement between these potential dust particles and PILS-IC or OPS measurements was found. This indicates that mineral dust was not characterised well by the ATOFMS. Indeed, the dust particle mass size distribution is mainly in the $>\mathrm{PM}_{2.5}$ fraction, but submicron particles dominate the dust particle number size distribution (see Gomes et al., 1990; Guieu et al., 2010) as confirmed by in situ and column-integrated particle size distribution measurements during the campaign (Denjean et al., 2016; Renard et al., 2016).

\subsubsection{Shipping}

Two V-rich particle classes (V and EC-V, 2 and $1 \%$ of ATOFMS mass respectively) were identified as originating from heavy fuel oil combustion. Both contained ${ }^{51} \mathrm{~V}^{+}$, ${ }^{67} \mathrm{VO}^{+},{ }^{56} \mathrm{Fe}^{+},{ }^{58} \mathrm{Ni}^{+}$and sulfate $\left({ }^{97} \mathrm{HSO}_{4}^{-}\right)$, which are typical markers for particles emitted by ships or oil refineries
(Ault et al., 2009; Healy et al., 2009). A small signal for MSA ${ }^{95} \mathrm{CH}_{3} \mathrm{SO}_{3}^{-}$) was present in EC-V particles. Internally mixed sodium, potassium, calcium, vanadium, nickel and iron particles have also been observed in ship exhaust particles using offline TEM-EDX and two-step laser mass spectrometry (L2MS) (Moldanová et al., 2009). Small signals for ${ }^{39} \mathrm{~K}^{+}$ and ${ }^{23} \mathrm{Na}^{+}$were found in the Corsica V-rich particles, but none for ${ }^{40} \mathrm{Ca}^{+}$.

Heavy fuel oil combustion aerosols have a strong presence in the Mediterranean (Becagli et al., 2017; Pey et al., 2010; Querol et al., 2009). There are more than 15 passenger ferry lanes incurring shipping traffic around the northern tip of the island; the closest pass is $\sim 16.5 \mathrm{~km}$ north and $\sim 12.5 \mathrm{~km}$ east of the site (Fig. 10). Ferries travelling around the northern tip of Corsica take approx. $1 \mathrm{~h}$ to reach Bastia and between all five ferry companies $\sim 50$ sailings take place per week. Both V-rich classes displayed strong north-westerly and south-westerly wind dependences (Fig. 10), consistent with the distribution of most ferry lanes (Fig. 10).

V-rich particles were identified as aged regional emissions. Most freshly emitted shipping particles are typically less than $300 \mathrm{~nm} D_{\mathrm{a}}$ (Healy et al., 2009). However, all shipping particles detected during this campaign had diameters larger than $300 \mathrm{~nm} D_{\mathrm{a}}$. Furthermore, it was unlikely that any fresh heavy 

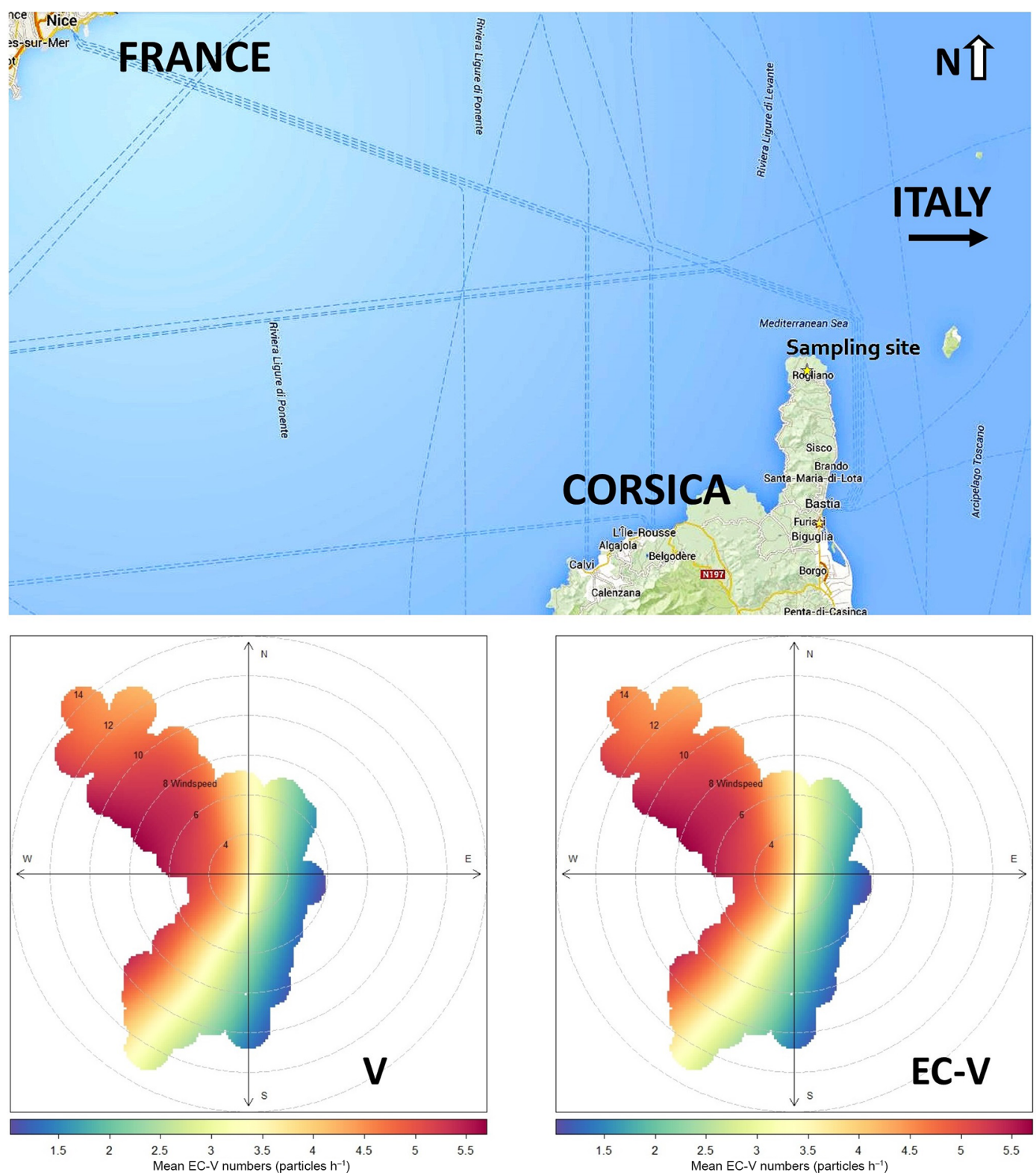

Figure 10. Passenger ferry lanes around the sampling site on Corsica (top) and wind speed and direction dependences (bottom) for ATOFMS V-rich particles observed during ADRIMED and SAF-MED.

oil combustion emissions were observed with the ATOFMS as the closest ferry lane is at least $12.5 \mathrm{~km}$ from the site. There are also no local power plants or refineries that could generate similar particles. EC-V and V particle numbers consistently featured a mode around $740 \mathrm{~nm} D_{\mathrm{a}}$, indicating that the observed particles were aged to some degree.

\subsection{Aged particle markers}

As a substantial number of ionised ATOFMS particles produced low-intensity signals in their negative ion mass spectra, or none at all, the average mass spectra are most representative of those species that ionised most efficiently, i.e. nitrate and sulfate. Ions that usually produce relatively small signals, such as oxalate or MSA, were expected to be underrepresented in the average mass spectra so an additional querying approach was taken to examine the mixing state of these species; particle numbers for classes found to contain these species are shown in Table 2. Oxalate $\left({ }^{89}(\mathrm{COO})_{2} \mathrm{H}^{-}\right)$ and MSA $\left({ }^{95} \mathrm{CH}_{3} \mathrm{SO}_{3}^{-}\right)$ions were queried for peak height between 1 and 5000 to include all mass spectra containing these species. These particles were then clustered using the $\mathrm{K}$-means algorithm to produce particle classes. 


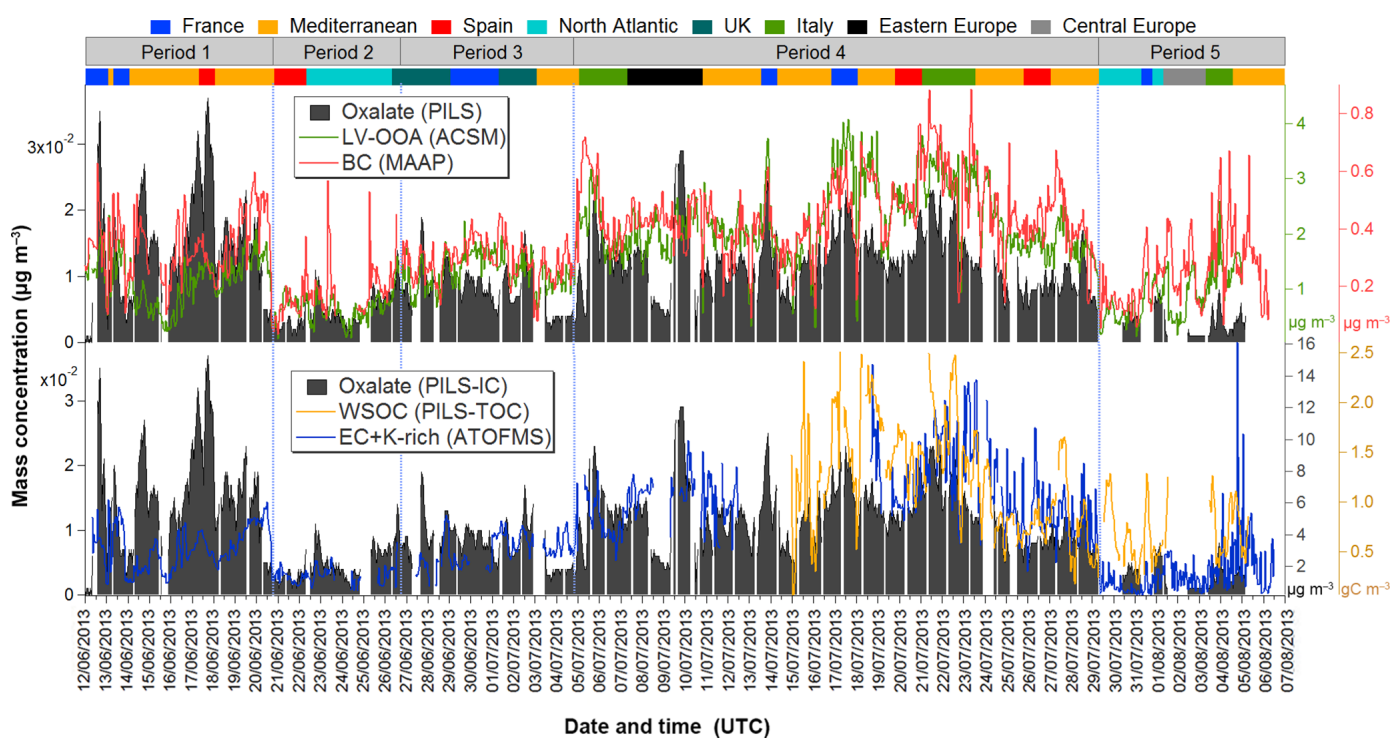

Figure 11. Hourly mass concentrations of the ACSM factor SV-OOA, BC (black carbon), WSOC (water soluble organic carbon) and ATOFMS EC + K-rich particles during ADRIMED and SAF-MED. Dates are dd/mm/yyyy.

\subsubsection{Oxalate}

The mixing states of particles containing oxalate as identified by single particle techniques is varied, and indicates oxalate formation either in fog/cloud processing or photochemical oxidation of biogenic and anthropogenic VOCs. Oxalate has been found in biomass burning particles (Healy et al., 2010; Yang et al., 2009) mixed with industrial combustion particles containing $\mathrm{Pb}$ and $\mathrm{Zn}$ (Moffet et al., 2008a, b), in aged sea salt (Yang et al., 2009) and in aged carbonaceous particles containing highly oxidised organics, non-oxygenated organics and amines (Pratt et al., 2009; Qin et al., 2012). Oxalic acid has been found preferentially enriched on Asian mineral dust over carbonaceous particles (Sullivan and Prather, 2007), while Fitzgerald et al. (2015) characterised cloud processed African dust as rich in sulfate and oxalate.

In our study, oxalate was found in $\sim 9600$ particles, i.e. $0.8 \%$ of the total particles ionised. The mixing states derived from this query are similar to those produced from general clustering and are varied, suggesting that poor ionisation efficiency did not prevent oxalate from being detected in certain types of particles.

From the querying approach it was apparent that K-rich particles produced more signals for oxalate than the more abundant carbonaceous particles. This could indicate preferential partitioning to K-rich particles or more extensive oxidation of the OC in those particles versus EC-rich ones. Of the queried oxalate particles, $52 \%$ were dominated by ${ }^{39} \mathrm{~K}^{+}$ and sulfate $(\sim 90 \%$ of all the queried particles contained sulfate), supporting the identification of the $\mathrm{K}^{-\mathrm{SO}_{x}}$-Oxalate class from the general approach. Particles most similar to $\mathrm{K}-\mathrm{NO}_{x}$ accounted for a further $33 \%$ and produced signals for nitrate, $\mathrm{EC}, \mathrm{CN}, \mathrm{CNO}$ and sulfate. In contrast only $2 \%$ of queried oxalate particles produced EC-rich positive mass spectra. Particles with typical dust tracers $(\mathrm{Fe}, \mathrm{Ca}, \mathrm{Al}$, aluminosilicates) accounted for $7 \%$ of the queried particles; this fraction applies to $\mathrm{PM}_{2.5}$ but would certainly be larger for $\mathrm{PM}_{10}$. The remaining queried oxalate particles were classified as aged sea salt (3\%), OC (2\%), V (0.7\%) and $\mathrm{Cu}-\mathrm{Pb}$ $(0.4 \%)$. If the queried oxalate particle numbers were considered representative of the whole ATOFMS data set, then biomass burning emissions play a large role in the fate of particle phase oxalate in the western Mediterranean.

The ATOFMS querying approach indicated a prevalence of oxalate mixed with K-rich particles; however correlations between PILS-IC oxalate and K-rich mass were poor. Better correlations were found with EC-rich and K-rich mass concentrations combined $\left(R^{2}=0.55\right)$, suggesting either that more EC particles actually contained oxalate than was detected or another particle type transported in the same air mass but which was not detected by the ATOFMS. Moderate correlations were also found between oxalate and LV-OOA $\left(R^{2}=0.54\right)$, WSOC $\left(R^{2}=0.55\right)$ and $\mathrm{BC}\left(R^{2}=0.55\right)$ mass concentrations (for the period 21 June-4 August); hourly mass concentrations for these species are shown in Fig. 11 (mean concentration of oxalate: $9.8 \mathrm{ng} \mathrm{m}^{-3}$ ). Oxalic acid is often the single most abundant water-soluble organic compound identified in ambient aerosols (Yu et al., 2005), which explains the agreement between oxalate and WSOC mass concentrations. While the humidity was relatively high (average of $70 \%$ ) throughout the two campaigns, so too was the solar radiation, with few instances of cloud or fog formation at the site. The association with SV-OOA also supports photochemical oxidation as the dominant oxalate formation mechanism. 


\subsubsection{MSA}

MSA is a well-established tracer for marine phytoplankton activity (Andreae and Crutzen, 1997; Hallquist et al., 2009; Gaston et al., 2010) formed from heterogeneous $\mathrm{OH}$ (daytime) and homogeneous $\mathrm{NO}_{3}$ (night-time) oxidation of DMS, the enzymatic cleavage product of dimethylsulfoniopropionate (DMSP), a compound produced by oceanic phytoplankton. It is therefore a good indicator of biogenic (marine) sulfate and its presence in aerosols typically indicates that they have undergone some marine transport, rather than being produced locally (Gaston et al., 2010). While MSA has been proposed to primarily contribute to particle growth in the atmosphere (Kreidenweis et al., 1989; Wyslouzil et al., 1991a, b), there is evidence that MSA can also contribute to new particle formation (Dawson et al., 2012; Willis et al., 2016). Recently, Sellegri et al. (2016) showed that iodine-containing species are likely precursors to new particle formation in the Mediterranean: a query of the ATOFMS ADRIMED and SAF-MED data set for iodine $(m / z-127)$ only returned 34 particles containing this ion. Iodine is rarely reported in ATOFMS studies and even then it is usually in low numbers of particles. Beddows et al. (2004) found $\sim 3600 \mathrm{PM}_{2.5}$ ATOFMS particles containing iodine at a rural background site in the UK. Both MSA and sulfate influence particle hygroscopicity, meaning that the enhanced production of either of these species by anthropogenic particle types could have implications for subsequent cloud droplet formation in both marine and inland environments (Lee et al., 2010; O'Dowd et al., 2004).

MSA was identified in $\sim 2700$ particles $(0.2 \%$ of total particles ionised). Sulfate was also found in all of these. The mixing states derived from the querying approach largely agrees with those from the general approach. Similar to oxalate, enhanced partitioning of MSA was observed for biomass combustion particles. Particles similar to the $\mathrm{K}-\mathrm{SO}_{x}$, EC-K-SO ${ }_{x}$ and K-EC-SO ${ }_{x}$ classes accounted for 45, 25 and $11 \%$ of the MSA queried particles. EC-V, $\mathrm{V}$ and $\mathrm{Cu}-\mathrm{Pb}$ classes contributed 11,4 and $1 \%$ respectively.

The preference for partitioning to combustion particles is in contrast to findings from Riverside, California (Gaston et al., 2010) where only small fractions of carbonaceous ATOFMS particle types contained MSA, and Cork, Ireland (Healy et al., 2010), where only one ATOFMS particle class of several carbonaceous classes identified was internally mixed with MSA. It has been suggested that accumulation of secondary species during transport over urban regions can potentially mask the detection of MSA by ATOFMS in carbonaceous particles (Pratt and Prather, 2009).

In addition, it has been demonstrated that the oxidation of biogenically emitted DMS to form MSA can be catalysed by vanadium, which has also been shown to enhance the conversion of anthropogenically produced $\mathrm{SO}_{2}$ to sulfate (Ault et al., 2010). About $40 \%$ of OC-V-sulfate (residual fuel combustion primarily from ships) particles and $33 \%$ of aged sea salt particles in Riverside contained MSA. No MSA could be clearly identified in aged sea salt particles in Corsica. $m / z-95$ was only found in fresh sea salt particles and was likely a result of $\mathrm{NaCl}_{2}$ as it was present in the typical isotopic ratio; i.e. its signal was smaller than $m / z-93$. This is again in contrast to the study in Cork Harbour (Healy et al., 2010), where none of the V-rich shipping classes were associated with MSA. However, the authors note that the sampling site in Cork Harbour was very close to shipping berths, so most shipping particles detected were expected to be freshly emitted.

$\mathrm{K}-\mathrm{OC}-\mathrm{SO}_{x}$ particles that identified with the general clustering approach produced average mass spectra with MSA signals. This was not supported by the querying approach: no OC-rich particles were found to contain MSA, or at least so few as to not resolve into their own clusters. No amine particles were identified in the MSA query. As discussed earlier, the presence of MSA in TMA and other amine-containing particles is possible, as indicated by laboratory studies of particle formation and growth from reactions between MSA, TMA (or methylamine and DMA) and water (Chen et al., $2015 \mathrm{a}, \mathrm{b}$ ). Amines have been frequently observed in marine aerosol (Facchini et al., 2008; Gaston et al., 2010; Müller et al., 2009; Sorooshian et al., 2009), and particulate amine levels have been found to correlate with particulate MSA levels (Sorooshian et al., 2009). Facchini et al. (2008) observed that MSA, DMA, and diethylamine were the most abundant organic species detected in fine particles in the North Atlantic during periods of high biological activity.

The remaining $3 \%$ of MSA queried particles was accounted for by particles containing dust tracers $(\mathrm{Fe}, \mathrm{Ca}, \mathrm{Al})$. The Riverside study found that no MSA was found on submicron dust and only $3 \%$ of supermicron dust contained MSA (Gaston et al., 2010). The authors expected this since the dust they observed was locally produced, unlike MSA. In contrast, internally mixed OC, sea salt, sulfate, titanium (dust) and MSA formed particles 1-2 $\mu \mathrm{m}$ in size at Mace Head during the EUCAARI project (Dall'Osto et al., 2010) and were associated with a period of subtropical maritime air originating from the Azores high-pressure region. The number of dust particles identified with the MSA query in this work were statistically too few to consider submicron/supermicron ratios. From these previous studies it is not unusual to detect MSA on dust particles; however it is unlikely that they represent significant surfaces for MSA to condense onto as most of the MSA mass measured in the Mediterranean to date has been found in the submicron fraction. This observation is also echoed by Gaston et al. (2010): $67 \%$ of the submicron particles in Riverside contained MSA.

In Riverside MSA-containing particles were also associated with fog processing markers ${ }^{81} \mathrm{HSO}_{3}^{-}$and hydroxymethanesulfonate (HMS, ${ }^{-111} \mathrm{HOCH}_{2} \mathrm{SO}_{3}^{-}$), highlighting aqueous phase chemistry as an important pathway in MSA formation (Bardouki and Rosa, 2002), as well as the hygro- 


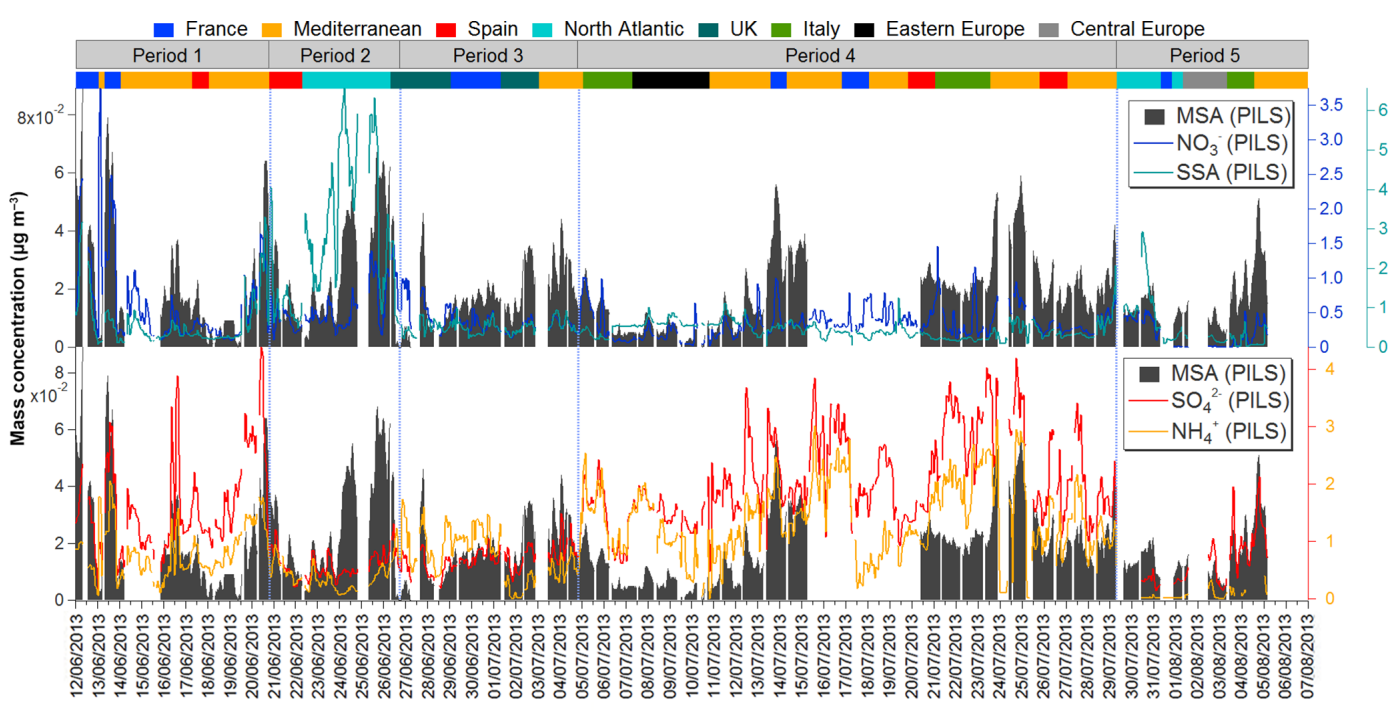

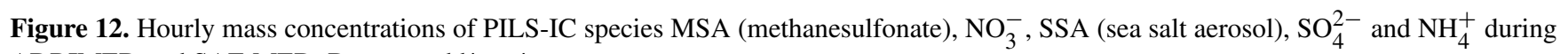
ADRIMED and SAF-MED. Dates are dd/mm/yyyy.

scopic nature of MSA (Barnes et al., 2006). Other studies correlated HMS with relative humidity $(\mathrm{RH})$ during stagnant fog events (Whiteaker and Prather, 2003); however in Riverside the HMS correlation with MSA suggested HMS formation was not due to local increases in RH. Rather, MSAparticles had undergone aqueous phase processing either in the marine environment or during subsequent transport. Unfortunately queries for $m / z-81$ and -111 did not return a statistically useful number of particles, and the summed signal for both of these groups was too low to produce a statistically useful time series.

Hourly PILS-IC mass concentrations of MSA (average of $21 \mathrm{ng} \mathrm{m}^{-3}$; lower than those measured in Paris; average of $122 \mathrm{ng} \mathrm{m}^{-3}$; Crippa et al., 2013) compared to Mace Head, Ireland and Erdemli, Turkey (shown in Fig. 12) did not correlate with any ATOFMS particle numbers or mass concentrations or with any other measurements over the whole sampling period. However, some correlations were found for certain periods. From 7 to 15 July MSA mass agreed well with that of PILS-IC $\mathrm{NO}_{3}^{-}$, while from 23 July to 3 August moderate correlations were found with PILS-IC $\mathrm{NO}_{3}^{-}\left(R^{2}=0.53\right)$, $\mathrm{SO}_{4}^{2-}\left(R^{2}=0.48\right)$ and $\mathrm{NH}_{4}^{+}\left(R^{2}=0.54\right)$, and $\mathrm{ACSM} \mathrm{NO}_{3}^{-}$ $\left(R^{2}=0.46\right)$. Increases in MSA mass coincided with sea salt events during Period 2 (Fig. 12), although there were no good correlations with SSA concentration, suggesting MSA was not present on sea salt particles but formation was enhanced by the influx of marine air masses.

\section{Conclusions}

As part of ChArMEx, two special observation periods on Corsica aimed to understand how the physical, chemical, op- tical properties and vertical distribution of aerosols affect the Mediterranean climate (ADRIMED), as well as develop a better understanding of the origins and particle properties of secondary organic aerosols (SAF-MED). Chemical composition is critical to achieving these aims. A single particle mass spectrometer (ATOFMS) provided detailed information on the mixing states and thereby sources of background aerosol in the western Mediterranean. Air mass trajectories and concurrent observations at the site were used to interpret ATOFMS observations. Overall, 27 distinct ATOFMS particle classes were identified from 1.2 million single particle mass spectra and grouped into eight general categories: EC, K-rich, Na-rich, amines, OC-rich, V-rich, Fe-rich and $\mathrm{Ca}-$ rich particles. Mass concentrations were reconstructed for the ATOFMS particle classes and were in good agreement with other quantitative measurements ( $\mathrm{PM}_{1}$, ACSM species, $\left.\mathrm{BC}\right)$. Total ATOFMS estimated mass $\left(\mathrm{PM}_{2.5}\right)$ accounted for 70 $90 \%$ of $\mathrm{PM}_{10}$ mass, most of which was comprised of regionally transported aerosols containing fossil fuel combustion (EC-rich) particles, and K-rich particles from biomass burning in northern Italy and the region surrounding the Black Sea. The accumulation of aerosols was favoured by repeated and extended periods of air mass stagnation over the western Mediterranean. Amine-containing particles were also assigned to regionally transported combustion sources from fossil fuel and biomass burning. Previous studies of aminecontaining particles found a strong dependence on relative humidity; this was not the case during these two campaigns, suggesting these particles were not formed locally.

Three other sources were also identified by the ATOFMS: local biomass burning, marine and shipping. Local biomass burning particles contributed little to $\mathrm{PM}_{2.5}$ particle numbers and mass concentrations but were easily distinguished from 
regional combustion particles. No local sources of fossil fuel combustion were identified. Although the local emissions did not contribute significantly to particle number or mass concentrations, the observations serve to highlight the ability of single particle measurements to distinguish between local and regional aerosol sources. Marine emissions comprised fresh and aged sea salt, the former detected mostly during one 5-day event and the latter detected throughout the sampling period. Mineral dust was not efficiently detected by the ATOFMS. Shipping particles were identified using markers for heavy fuel oil combustion as aged regional emissions which made only a small contribution to $\mathrm{PM}_{2.5}$ particle numbers and mass concentrations.

A query of the mixing states of oxalate, a photochemically aged aerosol marker, and MSA, a biogenic marine emissions marker, showed that the majority of particles containing oxalate also contained $\mathrm{K}$ and sulfate, indicative of aged biomass burning emissions. MSA was also strongly associated with biomass burning particles and to a lesser extent with shipping particles - probably related to transport time in the marine boundary layer.

Quantitative measurements by TEOM demonstrated that $\mathrm{PM}_{1}$ particles accounted for most $\mathrm{PM}_{10}$ mass concentrations over the whole sampling period. ACSM $\left(\mathrm{PM}_{1}\right)$ and PILSIC $\left(\mathrm{PM}_{10}\right)$ sulfate and ammonium mass concentrations were very similar, indicating most of the mass of these species was in the $\mathrm{PM}_{1}$ fraction. Accordingly, organics (36\%), sulfate $(16 \%)$ and ammonium (10\%) constituted most of the $\mathrm{PM}_{10}$ mass. Mass concentrations of EC- and K-rich particles were in good agreement with those of ACSM sulfate, ammonium and the LV-OOA factor (which accounted for $54 \%$ of the organics), as well as BC. ATOFMS mass spectra provided valuable source markers, allowing the identification of fossil fuel and biomass burning combustion sources. Combined, this information shows that these sources provided the primary particles, containing EC and OC, which then accumulated ammonium, sulfate and alkylamines during regional transport. The Mediterranean is a crossroad for air masses transporting different types of aerosols from natural and anthropogenic origins. Identifying these sources and apportioning aerosol mass to them is a key component of future work to mitigate their effects on the Mediterranean climate.

Data availability. Data are available on request from John Wenger (j.wenger@ucc.ie).

The Supplement related to this article is available online at https://doi.org/10.5194/acp-17-6975-2017-supplement.

Author contributions. PILS-IC, ACSM, TEOM PM 10 , TEOM $\mathrm{PM}_{1}$ and MAAP data were provided by J. Sciare; SMPS, OPS and meteorological data were provided by Météo-France. Jo- vanna Arndt prepared the manuscript with contributions from all co-authors.

Competing interests. The authors declare that they have no conflict of interest.

Acknowledgements. This research has received funding from the French National Research Agency (ANR) projects ADRIMED (grant ANR-11-BS56-0006) and SAF-MED (grant ANR-12BS06-0013). This work is part of the ChArMEx project supported by ADEME, CEA, CNRS-INSU and Météo-France through the multidisciplinary programme MISTRALS (Mediterranean Integrated Studies aT Regional And Local Scales). The station at Ersa was partly supported by the CORSiCA project funded by the Collectivité Territoriale de Corse through the Fonds Européen de Développement Régional of the European Operational Program 2007-2013 and the Contrat de Plan Etat-Région. Jovanna Arndt received a fellowship from the Irish Research Council. We gratefully acknowledge the contributions of Ian O'Connor and Eoin McGillicuddy (UCC), who provided excellent support for logistical arrangements and set-up on site.

Edited by: J.-L. Attie

Reviewed by: two anonymous referees

\section{References}

Allan, J. D., Jimenez, J. L., Williams, P. I., Alfarra, M. R., Bower, K. N., Jayne, J. T., Coe, H., and Worsnop, D. R.: Quantitative sampling using an Aerodyne aerosol mass spectrometer 1. Techniques of data interpretation and error analysis, J. Geophys. Res., 108, 1-10, https://doi.org/10.1029/2002JD002358, 2003.

Allen, J. O., Fergenson, D. P., Gard, E. E., Hughes, L. S., Morrical, B. D., Kleeman, M. J., Gross, D. S., Gälli, M. E., Prather, K. A., and Cass, G. R.: Particle Detection Efficiencies of Aerosol Time of Flight Mass Spectrometers under Ambient Sampling Conditions, Environ. Sci. Technol., 34, 211-217, https://doi.org/10.1021/es9904179, 2000.

Andreae, M. O. and Crutzen, P. J.: Atmospheric Aerosols: Biogeochemical Sources and Role in Atmospheric Chemistry, Science, 276, 1052-1058, https://doi.org/10.1126/science.276.5315.1052, 1997.

Ault, A. P., Moore, M. J., Furutani, H., and Prather, K. A.: Impact of emissions from the Los Angeles Port region on San Diego air quality during regional transport events, Environ. Sci. Technol., 43, 3500-3506, https://doi.org/10.1021/es8018918, 2009.

Ault, A. P., Gaston, C. J., Wang, Y., Dominguez, G., Thiemens, M. H., and Prather, K. A.: Characterization of the Single Particle Mixing State of Individual Ship Plume Events Measured at the Port of Los Angeles, Environ. Sci. Technol., 44, 1954-1061, https://doi.org/10.1021/es902985h, 2010.

Bardouki, H. and Rosa, M. Da: Kinetics and mechanism of the oxidation of dimethylsulfoxide (DMSO) and methanesulfinate $\left(\mathrm{MSI}^{-}\right)$by $\mathrm{OH}$ radicals in aqueous medium, Atmos. Environ., 36, 4627-4634, 2002. 
Barnes, I., Hjorth, J., and Mihalopoulos, N.: Dimethyl sulfide and dimethyl sulfoxide and their oxidation in the atmosphere., Chem. Rev., 106, 940-975, https://doi.org/10.1021/cr020529+, 2006.

Bates, T. S., Quinn, P. K., Frossard, A. A., Russell, L. M., Hakala, J., Petäjä, T., Kulmala, M., Covert, D. S., Cappa, C. D., Li, S.-M., Hayden, K. L., Nuaaman, I., McLaren, R., Massoli, P., Canagaratna, M. R., Onasch, T. B., Sueper, D., Worsnop, D. R., and Keene, W. C.: Measurements of ocean derived aerosol off the coast of California, J. Geophys. Res.-Atmos., 117, D00V15, https://doi.org/10.1029/2012JD017588, 2012.

Becagli, S., Anello, F., Bommarito, C., Cassola, F., Calzolai, G., Di Iorio, T., di Sarra, A., Gómez-Amo, J.-L., Lucarelli, F., Marconi, M., Meloni, D., Monteleone, F., Nava, S., Pace, G., Severi, M., Sferlazzo, D. M., Traversi, R., and Udisti, R.: Constraining the ship contribution to the aerosol of the central Mediterranean, Atmos. Chem. Phys., 17, 2067-2084, https://doi.org/10.5194/acp17-2067-2017, 2017.

Beddows, D. C. S., Donovan, R. J., Harrison, R. M., Heal, M. R., Kinnersley, R. P., King, M. D., Nicholson, D. H., and Thompson, K. C.: Correlations in the chemical composition of rural background atmospheric aerosol in the UK determined in real time using time-of-flight mass spectrometry, J. Environ. Monitor., 6, 124-133, https://doi.org/10.1039/b311209h, 2004.

Beekmann, M., Prévôt, A. S. H., Drewnick, F., Sciare, J., Pandis, S. N., Denier van der Gon, H. A. C., Crippa, M., Freutel, F., Poulain, L., Ghersi, V., Rodriguez, E., Beirle, S., Zotter, P., von der Weiden-Reinmüller, S.-L., Bressi, M., Fountoukis, C., Petetin, H., Szidat, S., Schneider, J., Rosso, A., El Haddad, I., Megaritis, A., Zhang, Q. J., Michoud, V., Slowik, J. G., Moukhtar, S., Kolmonen, P., Stohl, A., Eckhardt, S., Borbon, A., Gros, V., Marchand, N., Jaffrezo, J. L., Schwarzenboeck, A., Colomb, A., Wiedensohler, A., Borrmann, S., Lawrence, M., Baklanov, A., and Baltensperger, U.: In situ, satellite measurement and model evidence on the dominant regional contribution to fine particulate matter levels in the Paris megacity, Atmos. Chem. Phys., 15, 9577-9591, https://doi.org/10.5194/acp-15-9577-2015, 2015.

Bein, K. J., Zhao, Y., Pekney, N. J., Davidson, C. I., Johnston, M. V., and Wexler, A. S.: Identification of sources of atmospheric PM at the Pittsburgh Supersite - Part II: Quantitative comparisons of single particle, particle number, and particle mass measurements, Atmos. Environ., 40, 424-444, https://doi.org/10.1016/j.atmosenv.2006.01.064, 2006.

Bergametti, G., Dutot, A.-L., Buat-Ménard, P., Losno, R., and Remoudaki, E.: Seasonal variability of the elemental composition of atmospheric aerosol particles over the northwestern Mediterranean, Tellus B, 41, 353-361, https://doi.org/10.1111/j.16000889.1989.tb00314.x, 1989.

Bhave, P. V., Fergenson, D. P., Prather, K. A., and Cass, G. R.: Source apportionment of fine particulate matter by clustering single-particle data: tests of receptor model accuracy, Environ. Sci. Technol., 35, 2060-2072, 2001.

Bhave, P. V., Kleeman, M. J., Allen, J. O., Hughes, L. S., Prather, K. A., and Cass, G. R.: Evaluation of an Air Quality Model for the Size and Composition of SourceOriented Particle Classes, Environ. Sci. Technol., 36, 2154 2163, https://doi.org/10.1021/es0112700, 2002.

Cahill, J. F., Suski, K., Seinfeld, J. H., Zaveri, R. A., and Prather, K. A.: The mixing state of carbonaceous aerosol particles in northern and southern California measured during CARES and CalNex 2010, Atmos. Chem. Phys., 12, 10989-11002, https://doi.org/10.5194/acp-12-10989-2012, 2012.

Cahill, J. F., Darlington, T. K., Wang, X., Mayer, J., Spencer, M. T., Holecek, J. C., Reed, B. E., and Prather, K. A.: Development of a High-Pressure Aerodynamic Lens for Focusing Large Particles $(4-10 \mu \mathrm{m})$ into the Aerosol Time-ofFlight Mass Spectrometer, Aerosol Sci. Tech., 48, 948-956, https://doi.org/10.1080/02786826.2014.947400, 2014.

Chan, L. P. and Chan, C. K.: Role of the aerosol phase state in ammonia/amines exchange reactions, Environ. Sci. Technol., 47, 5755-5762, https://doi.org/10.1021/es4004685, 2013.

Chen, H., Ezell, M. J., Arquero, K. D., Varner, M. E., Dawson, M. L., Gerber, R. B., and Finlayson-Pitts, B. J.: New particle formation and growth from methanesulfonic acid, trimethylamine and water, Phys. Chem. Chem. Phys., 17, 13699-13709, https://doi.org/10.1039/C5CP00838G, 2015a.

Chen, H., Varner, M. E., Gerber, R. B., and Finlayson-Pitts, B. J.: Reactions of Methanesulfonic Acid with Amines and Ammonia as a Source of New Particles in Air, J. Phys. Chem. B, 120, 15261536, https://doi.org/10.1021/acs.jpcb.5b07433, 2015b.

Claeys, M., Roberts, G., Mallet, M., Arndt, J., Sellegri, K., Sciare, J., Wenger, J., and Sauvage, B.: Optical, physical and chemical properties of aerosols transported to a coastal site in the Western Mediterranean: Focus on primary marine aerosols, Atmos. Chem. Phys. Discuss., https://doi.org/10.5194/acp-2016-602, in review, 2016.

Corbin, J. C., Rehbein, P. J. G., Evans, G. J., and Abbatt, J. P. D.: Combustion particles as ice nuclei in an urban environment: Evidence from single-particle mass spectrometry, Atmos. Environ., 51, 286-292, https://doi.org/10.1016/j.atmosenv.2012.01.007, 2012.

Crippa, M., El Haddad, I., Slowik, J. G., DeCarlo, P. F., Mohr, C., Heringa, M. F., Chirico, R., Marchand, N., Sciare, J., Baltensperger, U., and Prévôt, A. S. H.: Identification of marine and continental aerosol sources in Paris using high resolution aerosol mass spectrometry, J. Geophys. Res.-Atmos., 118, 1950-1963, https://doi.org/10.1002/jgrd.50151, 2013.

Dall'Osto, M. and Harrison, R. M.: Chemical characterisation of single airborne particles in Athens (Greece) by ATOFMS, Atmos. Environ., 40, 7614-7631, https://doi.org/10.1016/j.atmosenv.2006.06.053, 2006.

Dall'Osto, M., Beddows, D. C. S., Kinnersley, R. P., Harrison, R. M., Donovan, R. J., and Heal, M. R.: Characterization of individual airborne particles by using aerosol time-of-flight mass spectrometry at Mace Head, Ireland, J. Geophys. Res., 109, D21302, https://doi.org/10.1029/2004JD004747, 2004.

Dall'Osto, M., Booth, M. J., Smith, W., Fisher, R., and Harrison, R. M.: A Study of the Size Distributions and the Chemical Characterization of Airborne Particles in the Vicinity of a Large Integrated Steelworks, Aerosol Sci. Tech., 42, 981-991, https://doi.org/10.1080/02786820802339587, 2008.

Dall'Osto, M., Ceburnis, D., Martucci, G., Bialek, J., Dupuy, R., Jennings, S. G., Berresheim, H., Wenger, J., Healy, R., Facchini, M. C., Rinaldi, M., Giulianelli, L., Finessi, E., Worsnop, D., Ehn, M., Mikkilä, J., Kulmala, M., and O’Dowd, C. D.: Aerosol properties associated with air masses arriving into the North East Atlantic during the 2008 Mace Head EUCAARI intensive observing period: an overview, Atmos. Chem. Phys., 10, 8413-8435, https://doi.org/10.5194/acp-10-8413-2010, 2010. 
Dall'Osto, M., Querol, X., Alastuey, A., Minguillon, M. C., Alier, M., Amato, F., Brines, M., Cusack, M., Grimalt, J. O., Karanasiou, A., Moreno, T., Pandolfi, M., Pey, J., Reche, C., Ripoll, A., Tauler, R., Van Drooge, B. L., Viana, M., Harrison, R. M., Gietl, J., Beddows, D., Bloss, W., O’Dowd, C., Ceburnis, D., Martucci, G., Ng, N. L., Worsnop, D., Wenger, J., Mc Gillicuddy, E., Sodeau, J., Healy, R., Lucarelli, F., Nava, S., Jimenez, J. L., Gomez Moreno, F., Artinano, B., Prévôt, A. S. H., Pfaffenberger, L., Frey, S., Wilsenack, F., Casabona, D., Jiménez-Guerrero, P., Gross, D., and Cots, N.: Presenting SAPUSS: Solving Aerosol Problem by Using Synergistic Strategies in Barcelona, Spain, Atmos. Chem. Phys., 13, 8991-9019, https://doi.org/10.5194/acp13-8991-2013, 2013.

Dall'Osto, M., Beddows, D. C. S., Gietl, J. K., Olatunbosun, O. A., Yang, X., and Harrison, R. M.: Characteristics of tyre dust in polluted air: Studies by single particle mass spectrometry (ATOFMS), Atmos. Environ., 94, 224-230, https://doi.org/10.1016/j.atmosenv.2014.05.026, 2014.

Dall'Osto, M., Beddows, D. C. S., McGillicuddy, E. J., Esser-Gietl, J. K., Harrison, R. M., and Wenger, J. C.: On the simultaneous deployment of two single-particle mass spectrometers at an urban background and a roadside site during SAPUSS, Atmos. Chem. Phys., 16, 9693-9710, https://doi.org/10.5194/acp16-9693-2016, 2016.

Dawson, M. L., Varner, M. E., Perraud, V., Ezell, M. J., Gerber, R. B., and Finlayson-Pitts, B. J.: Simplified mechanism for new particle formation from methanesulfonic acid, amines, and water via experiments and ab initio calculations., Proc. Natl. Acad. Sci. U. S. A., 109, 18719-24, https://doi.org/10.1073/pnas.1211878109, 2012.

DeCarlo, P., Slowik, J., Worsnop, D., Davidovits, P., and Jimenez, J.: Particle Morphology and Density Characterization by Combined Mobility and Aerodynamic Diameter Measurements. Part 1: Theory, Aerosol Sci. Tech., 38, 1185-1205, https://doi.org/10.1080/027868290903907, 2004.

Denjean, C., Cassola, F., Mazzino, A., Triquet, S., Chevaillier, S., Grand, N., Bourrianne, T., Momboisse, G., Sellegri, K., Schwarzenbock, A., Freney, E., Mallet, M., and Formenti, P.: Size distribution and optical properties of mineral dust aerosols transported in the western Mediterranean, Atmos. Chem. Phys., 16, 1081-1104, https://doi.org/10.5194/acp16-1081-2016, 2016.

Denkenberger, K. A., Moffet, R. C., Holecek, J. C., Rebotier, T. P., and Prather, K. A.: Real-Time, Single-Particle Measurements of Oligomers in Aged Ambient Aerosol Particles, Environ. Sci. Technol., 41, 5439-5446, https://doi.org/10.1021/es0703291, 2007.

Draxler, R. R. and Hess, G. D.: An Overview of the HYSPLIT_4 Modelling System for Trajectories, Dispersion, and Deposition, Aust. Meteorol. Mag., 47, 295-308, 1998.

El Haddad, I., Marchand, N., Wortham, H., Piot, C., Besombes, J.L., Cozic, J., Chauvel, C., Armengaud, A., Robin, D., and Jaffrezo, J.-L.: Primary sources of $\mathrm{PM}_{2.5}$ organic aerosol in an industrial Mediterranean city, Marseille, Atmos. Chem. Phys., 11, 2039-2058, https://doi.org/10.5194/acp-11-2039-2011, 2011.

El Haddad, I., D’ Anna, B., Temime-Roussel, B., Nicolas, M., Boreave, A., Favez, O., Voisin, D., Sciare, J., George, C., Jaffrezo, J.-L., Wortham, H., and Marchand, N.: Towards a better understanding of the origins, chemical composition and aging of oxy- genated organic aerosols: case study of a Mediterranean industrialized environment, Marseille, Atmos. Chem. Phys., 13, 78757894, https://doi.org/10.5194/acp-13-7875-2013, 2013.

Facchini, M. C., Decesari, S., Rinaldi, M., Carbone, C., Finessi, E., Mircea, M., Fuzzi, S., Moretti, F., Tagliavini, E., Ceburnis, D., and O'Dowd, C. D.: Important source of marine secondary organic aerosol from biogenic amines., Environ. Sci. Technol., 42, 9116-9121, https://doi.org/10.1021/es8018385, 2008.

Favez, O., Cachier, H., Sciare, J., and Le Moullec, Y.: Characterization and contribution to $\mathrm{PM}_{2.5}$ of semi-volatile aerosols in Paris (France), Atmos. Environ., 41, 7969-7976, https://doi.org/10.1016/j.atmosenv.2007.09.031, 2007.

Ferge, T., Karg, E., Schröppel, a., Coffee, K. R., Tobias, H. J., Frank, M., Gard, E. E., and Zimmermann, R.: Fast determination of the relative elemental and organic carbon content of aerosol samples by on-line single-particle aerosol time-offlight mass spectrometry, Environ. Sci. Technol., 40, 3327-3335, https://doi.org/10.1021/es050799k, 2006.

Fitzgerald, E., Ault, A. P., Zauscher, M. D., Mayol-Bracero, O. L., and Prather, K. A.: Comparison of the mixing state of long-range transported Asian and African mineral dust, Atmos. Environ., 115, 19-25, https://doi.org/10.1016/j.atmosenv.2015.04.031, 2015.

Furutani, H., Dall'Osto, M., Roberts, G., and Prather, K. A.: Assessment of the relative importance of atmospheric aging on $\mathrm{CCN}$ activity derived from field observations, Atmos. Environ., 42, 3130-3142, https://doi.org/10.1016/j.atmosenv.2007.09.024, 2008.

Gangoiti, G., Millán, M. M., Salvador, R., and Mantilla, E.: Longrange transport and re-circulation of pollutants in the western Mediterranean during the project Regional Cycles of Air Pollution in the West-Central Mediterranean, Atmos. Environ., 35, 6267-6276, https://doi.org/10.1016/S1352-2310(01)00440$\mathrm{X}, 2001$.

Gard, E., Mayer, J. E., Morrical, B. D., Dienes, T., Fergenson, D. P., and Prather, K. A.: Real-Time Analysis of Individual Atmospheric Aerosol Particles: Design and Performance of a Portable ATOFMS, Anal. Chem., 69, 4083-4091, https://doi.org/10.1021/ac970540n, 1997.

Gard, E. E., Kleeman, M. J., Gross, D. S., Hughes, L. S., Allen, J. O., Morrical, B. D., Fergenson, D. P., Dienes, T., Galli, M. E., Johnson, R. J., Cass, G. R., and Prather, K. A.: Direct Observation of Heterogeneous Chemistry in the Atmosphere, Science, 279, 1184-1187, https://doi.org/10.1126/science.279.5354.1184, 1998.

Gaston, C. J., Pratt, K. A., Qin, X., and Prather, K. A.: Real-Time detection and mixing state of methanesulfonate in single particles at an inland urban location during a phytoplankton bloom, Environ. Sci. Technol., 44, 1566-1572, https://doi.org/10.1021/es902069d, 2010.

Giorio, C., Tapparo, A., Dall'Osto, M., Harrison, R. M., Beddows, D. C. S., Di Marco, C., and Nemitz, E.: Comparison of three techniques for analysis of data from an Aerosol Timeof-Flight Mass Spectrometer, Atmos. Environ., 61, 316-326, https://doi.org/10.1016/j.atmosenv.2012.07.054, 2012.

Gomes, L., Bergametti, G., Coudé-Gaussen, G., and Rognon, P.: Submicron desert dusts: A sandblasting process, J. Geophys. Res., 95, 13927, https://doi.org/10.1029/JD095iD09p13927, 1990. 
Gross, D. S., Gälli, M. E., Silva, P. J., and Prather, K. A.: Relative sensitivity factors for alkali metal and ammonium cations in single-particle aerosol time-of-flight mass spectra, Anal. Chem., 72, 416-422, 2000a.

Gross, D. S., Galli, M. E., Silva, P. J., Wood, S. H., Liu, D.-Y., and Prather, K. A.: Single Particle Characterization of Automobile and Diesel Truck Emissions in the Caldecott Tunnel, Aerosol Sci. Tech., 32, 152-163, https://doi.org/10.1080/027868200303858, 2000b.

Gross, D. S., Atlas, R., Rzeszotarski, J., Turetsky, E., Christensen, J., Benzaid, S., Olson, J., Smith, T., Steinberg, L., and Sulman, J.: Environmental chemistry through intelligent atmospheric data analysis, Environ. Model. Softw., 25, 760-769, https://doi.org/10.1016/j.envsoft.2009.12.001, 2010.

Guazzotti, S. A., Whiteaker, J. R., Suess, D. T., Coffee, K. R., and Prather, K. A.: Real-time measurements of the chemical composition of size-resolved particles during a Santa Ana wind episode, California USA, Atmos. Environ., 35, 3229-3240, https://doi.org/10.1016/S1352-2310(01)00140-6, 2001.

Guieu, C., Dulac, F., Desboeufs, K., Wagener, T., Pulido-Villena, E., Grisoni, J.-M., Louis, F., Ridame, C., Blain, S., Brunet, C., Bon Nguyen, E., Tran, S., Labiadh, M., and Dominici, J.-M.: Large clean mesocosms and simulated dust deposition: a new methodology to investigate responses of marine oligotrophic ecosystems to atmospheric inputs, Biogeosciences, 7, 27652784, https://doi.org/10.5194/bg-7-2765-2010, 2010.

Hallquist, M., Wenger, J. C., Baltensperger, U., Rudich, Y., Simpson, D., Claeys, M., Dommen, J., Donahue, N. M., George, C., Goldstein, A. H., Hamilton, J. F., Herrmann, H., Hoffmann, T., Iinuma, Y., Jang, M., Jenkin, M. E., Jimenez, J. L., Kiendler-Scharr, A., Maenhaut, W., McFiggans, G., Mentel, Th. F., Monod, A., Prévôt, A. S. H., Seinfeld, J. H., Surratt, J. D., Szmigielski, R., and Wildt, J.: The formation, properties and impact of secondary organic aerosol: current and emerging issues, Atmos. Chem. Phys., 9, 5155-5236, doi:10.5194/acp-9-51552009, 2009.

Harrison, R. M., Dall'Osto, M., Beddows, D. C. S., Thorpe, A. J., Bloss, W. J., Allan, J. D., Coe, H., Dorsey, J. R., Gallagher, M., Martin, C., Whitehead, J., Williams, P. I., Jones, R. L., Langridge, J. M., Benton, A. K., Ball, S. M., Langford, B., Hewitt, C. N., Davison, B., Martin, D., Petersson, K. F., Henshaw, S. J., White, I. R., Shallcross, D. E., Barlow, J. F., Dunbar, T., Davies, F., Nemitz, E., Phillips, G. J., Helfter, C., Di Marco, C. F., and Smith, S.: Atmospheric chemistry and physics in the atmosphere of a developed megacity (London): an overview of the REPARTEE experiment and its conclusions, Atmos. Chem. Phys., 12, 3065-3114, https://doi.org/10.5194/acp-12-3065-2012, 2012.

Healy, R. M., O'Connor, I. P., Hellebust, S., Allanic, A., Sodeau, J. R., and Wenger, J. C.: Characterisation of single particles from in-port ship emissions, Atmos. Environ., 43, 6408-6414, https://doi.org/10.1016/j.atmosenv.2009.07.039, 2009.

Healy, R. M., Hellebust, S., Kourtchev, I., Allanic, A., O'Connor, I. P., Bell, J. M., Healy, D. A., Sodeau, J. R., and Wenger, J. C.: Source apportionment of $\mathrm{PM}_{2.5}$ in Cork Harbour, Ireland using a combination of single particle mass spectrometry and quantitative semi-continuous measurements, Atmos. Chem. Phys., 10, 9593-9613, https://doi.org/10.5194/acp-10-9593-2010, 2010.

Healy, R. M., Sciare, J., Poulain, L., Kamili, K., Merkel, M., Müller, T., Wiedensohler, A., Eckhardt, S., Stohl, A., Sarda-Estève, R.,
McGillicuddy, E., O'Connor, I. P., Sodeau, J. R., and Wenger, J. C.: Sources and mixing state of size-resolved elemental carbon particles in a European megacity: Paris, Atmos. Chem. Phys., 12, 1681-1700, https://doi.org/10.5194/acp-12-1681-2012, 2012.

Healy, R. M., Sciare, J., Poulain, L., Crippa, M., Wiedensohler, A., Prévôt, A. S. H., Baltensperger, U., Sarda-Estève, R., McGuire, M. L., Jeong, C.-H., McGillicuddy, E., O’Connor, I. P., Sodeau, J. R., Evans, G. J., and Wenger, J. C.: Quantitative determination of carbonaceous particle mixing state in Paris using single-particle mass spectrometer and aerosol mass spectrometer measurements, Atmos. Chem. Phys., 13, 9479-9496, https://doi.org/10.5194/acp-13-9479-2013, 2013.

Healy, R. M., Evans, G. J., Murphy, M., Jurányi, Z., Tritscher, T., Laborde, M., Weingartner, E., Gysel, M., Poulain, L., Kamilli, K. A., Wiedensohler, A., O'Connor, I. P., McGillicuddy, E., Sodeau, J. R., and Wenger, J. C.: Predicting hygroscopic growth using single particle chemical composition estimates, J. Geophys. Res.-Atmos., 119, 9567-9577, https://doi.org/10.1002/2014JD021888, 2014.

Healy, R. M., Evans, G. J., Murphy, M., Sierau, B., Arndt, J., McGillicuddy, E., O’Connor, I. P., Sodeau, J. R., and Wenger, J. C.: Single-particle speciation of alkylamines in ambient aerosol at five European sites, Anal. Bioanal. Chem., 407, 5899-5909, https://doi.org/10.1007/s00216-014-8092-1, 2015.

Herich, H., Kammermann, L., Friedman, B., Gross, D. S., Weingartner, E., Lohmann, U., Spichtinger, P., Gysel, M., Baltensperger, U., and Cziczo, D. J.: Subarctic atmospheric aerosol composition: 2. Hygroscopic growth properties, J. Geophys. Res., 114, 1-14, https://doi.org/10.1029/2008JD011574, 2009.

Hu, D., Li, C., Chen, H., Chen, J., Ye, X., Li, L., Yang, X., Wang, X., Mellouki, A., and Hu, Z.: Hygroscopicity and optical properties of alkylaminium sulfates, J. Environ. Sci., 26, 37-43, https://doi.org/10.1016/S1001-0742(13)60378-2, 2014.

Kanakidou, M., Mihalopoulos, N., Kindap, T., Im, U., Vrekoussis, M., Gerasopoulos, E., Dermitzaki, E., Unal, A., Koçak, M., Markakis, K., Melas, D., Kouvarakis, G., Youssef, A. F., Richter, A., Hatzianastassiou, N., Hilboll, A., Ebojie, F., Wittrock, F., von Savigny, C., Burrows, J. P., Ladstaetter-Weissenmayer, A., and Moubasher, H.: Megacities as hot spots of air pollution in the East Mediterranean, Atmos. Environ., 45, 1223-1235, https://doi.org/10.1016/j.atmosenv.2010.11.048, 2011.

Karanasiou, A., Moreno, T., Amato, F., Lumbreras, J., Narros, A., Borge, R., Tobías, A., Boldo, E., Linares, C., Pey, J., Reche, C., Alastuey, A., and Querol, X.: Road dust contribution to PM levels - Evaluation of the effectiveness of street washing activities by means of Positive Matrix Factorization, Atmos. Environ., 45, 2193-2201, https://doi.org/10.1016/j.atmosenv.2011.01.067, 2011.

Karanasiou, A., Querol, X., Alastuey, A., Perez, N., Pey, J., Perrino, C., Berti, G., Gandini, M., Poluzzi, V., Ferrari, S., de la Rosa, J., Pascal, M., Samoli, E., Kelessis, A., Sunyer, J., Alessandrini, E., Stafoggia, M., and Forastiere, F.: Particulate matter and gaseous pollutants in the Mediterranean Basin: results from the MED-PARTICLES project, Sci. Total Environ., 488-489, 297 315, https://doi.org/10.1016/j.scitotenv.2014.04.096, 2014.

Karanasiou, A. A., Sitaras, I. E., Siskos, P. A., and Eleftheriadis, K.: Size distribution and sources of trace metals and n-alkanes in the Athens urban aerosol during summer, Atmos. Environ., 
41, 2368-2381, https://doi.org/10.1016/j.atmosenv.2006.11.006, 2007.

Karanasiou, A. A., Siskos, P. A., and Eleftheriadis, K.: Assessment of source apportionment by Positive Matrix Factorization analysis on fine and coarse urban aerosol size fractions, Atmos. Environ., 43, 3385-3395, https://doi.org/10.1016/j.atmosenv.2009.03.051, 2009.

Kreidenweis, S. M., Flagan, R. C., Seinfeld, J. H., and Okuyama, K.: Binary nucleation of methanesulfonic acid and water, J. Aerosol Sci., 20, 585-607, https://doi.org/10.1016/00218502(89)90105-5, 1989.

Kubilay, N. and Saydam, A. C.: Trace elements in atmospheric particulates over the eastern Mediterranean; Concentrations, sources, and temporal variability, Atmos. Environ., 29, 22892300, https://doi.org/10.1016/1352-2310(95)00101-4, 1995.

de la Paz, D., Vedrenne, M., Borge, R., Lumbreras, J., de Andrés, J. M., Pérez, J., Rodríguez, E., Karanasiou, A., Moreno, T., Boldo, E., and Linares, C.: Modelling Saharan dust transport into the Mediterranean basin with CMAQ, Atmos. Environ., 70, 337350, https://doi.org/10.1016/j.atmosenv.2013.01.013, 2013.

Lambert, D., Mallet, M., Ducrocq, V., Dulac, F., Gheusi, F., and Kalthoff, N.: CORSiCA: a Mediterranean atmospheric and oceanographic observatory in Corsica within the framework of HyMeX and ChArMEx, Adv. Geosci., 26, 125-131, https://doi.org/10.5194/adgeo-26-125-2011, 2011.

Lea-Langton, A. R., Baeza-Romero, M. T., Boman, G. V., Brooks, B., Wilson, A. J. M., Atika, F., Bartle, K. D., Jones, J. M., and Williams, A.: A study of smoke formation from wood combustion, Fuel Process. Technol., 137, 327-332, https://doi.org/10.1016/j.fuproc.2015.03.020, 2015.

Lee, G., Park, J., Jang, Y., Lee, M., Kim, K.-R., Oh, J.-R., Kim, D., Yi, H.-I., and Kim, T.-Y.: Vertical variability of seawater DMS in the South Pacific Ocean and its implication for atmospheric and surface seawater DMS, Chemosphere, 78, $1063-$ 1070, https://doi.org/10.1016/j.chemosphere.2009.10.054, 2010.

Lelieveld, J., Berresheim, H., Borrmann, S., Crutzen, P. J., Dentener, F. J., Fischer, H., Feichter, J., Flatau, P. J., Heland, J., Holzinger, R., Korrmann, R., Lawrence, M. G., Levin, Z., Markowicz, K. M., Mihalopoulos, N., Minikin, A., Ramanathan, V., De Reus, M., Roelofs, G. J., Scheeren, H. a, Sciare, J., Schlager, H., Schultz, M., Siegmund, P., Steil, B., Stephanou, E. G., Stier, P., Traub, M., Warneke, C., Williams, J., and Ziereis, H.: Global air pollution crossroads over the Mediterranean, Science, 298, 794-799, https://doi.org/10.1126/science.1075457, 2002

Liu, D. Y., Wenzel, R. J., Prather, K. A., Liu, D. Y., Edgerton, E. S., and Prather, K. A.: Aerosol time-of-flight mass spectrometry during the Atlanta Supersite Experiment: 1. Measurements, J. Geophys. Res., 108, 8426, https://doi.org/10.1029/2001JD001562, 2003

Mallet, M., Dulac, F., Formenti, P., Nabat, P., Sciare, J., Roberts, G., Pelon, J., Ancellet, G., Tanré, D., Parol, F., Denjean, C., Brogniez, G., di Sarra, A., Alados-Arboledas, L., Arndt, J., Auriol, F., Blarel, L., Bourrianne, T., Chazette, P., Chevaillier, S., Claeys, M., D’Anna, B., Derimian, Y., Desboeufs, K., Di Iorio, T., Doussin, J.-F., Durand, P., Féron, A., Freney, E., Gaimoz, C., Goloub, P., Gómez-Amo, J. L., Granados-Muñoz, M. J., Grand, N., Hamonou, E., Jankowiak, I., Jeannot, M., Léon, J.-F., Maillé, M., Mailler, S., Meloni, D., Menut, L., Momboisse, G., Nico- las, J., Podvin, T., Pont, V., Rea, G., Renard, J.-B., Roblou, L., Schepanski, K., Schwarzenboeck, A., Sellegri, K., Sicard, M., Solmon, F., Somot, S., Torres, B., Totems, J., Triquet, S., Verdier, N., Verwaerde, C., Waquet, F., Wenger, J., and Zapf, P.: Overview of the Chemistry-Aerosol Mediterranean Experiment/Aerosol Direct Radiative Forcing on the Mediterranean Climate (ChArMEx/ADRIMED) summer 2013 campaign, Atmos. Chem. Phys., 16, 455-504, https://doi.org/10.5194/acp-16455-2016, 2016.

Maricq, M. M. and Xu, N.: The effective density and fractal dimension of soot particles from premixed flames and motor vehicle exhaust, J. Aerosol Sci., 35, 1251-1274, https://doi.org/10.1016/j.jaerosci.2004.05.002, 2004.

Marmer, E. and Langmann, B.: Impact of ship emissions on the Mediterranean summertime pollution and climate: A regional model study, Atmos. Environ., 39, 4659-4669, https://doi.org/10.1016/j.atmosenv.2005.04.014, 2005.

McGillicuddy, E. J.: Real Time Analysis of Atmospheric Single Particles in Urban Environments using Aerosol Time of Flight Mass Spectrometry, Univesity College Cork, 2014.

Michoud, V., Sciare, J., Sauvage, S., Dusanter, S., Léonardis, T., Gros, V., Kalogridis, C., Zannoni, N., Féron, A., Petit, J.-E., Crenn, V., Baisnée, D., Sarda-Estève, R., Bonnaire, N., Marchand, N., DeWitt, H. L., Pey, J., Colomb, A., Gheusi, F., Szidat, S., Stavroulas, I., Borbon, A., and Locoge, N.: Organic carbon at a remote site of the western Mediterranean Basin: composition, sources and chemistry during the ChArMEx SOP2 field experiment, Atmos. Chem. Phys. Discuss., https://doi.org/10.5194/acp2016-955, in review, 2017.

Millán, M. M. and Salvador, R.: Photooxidant dynamics in the Mediterranean basin in summer: results from European research projects, J. Geophys. Res., 102, 8811-8823, https://doi.org/10.1029/96JD03610, 1997.

Millán, M. M., Mantilla, E., Salvador, R., Carratalá, A., Sanz, M. J., Alonso, L., Gangoiti, G., and Navazo, M. Ozone cycles in the western Mediterranean basin: interpretation of monitoring data in complex coastal terrain, J. Appl. Meteorol., 39, 487-508, https://doi.org/10.1175/15200450(2000)039<0487:OCITWM>2.0.CO;2, 2000.

Millán, M. M., Sanz, M. J., Salvador, R., and Mantilla, E.: Atmospheric dynamics and ozone cycles related to nitrogen deposition in the western Mediterranean, Environ. Pollut., 118, 167-186, https://doi.org/10.1016/S0269-7491(01)00311-6, 2002.

Moffet, R. C. and Prather, K. A.: In-situ measurements of the mixing state and optical properties of soot with implications for radiative forcing estimates, P. Natl. Acad. Sci. USA, 106, 11872 11877, https://doi.org/10.1073/pnas.0900040106, 2009.

Moffet, R. C., Desyaterik, Y., Hopkins, R. J., Tivanski, A. V., Gilles, M. K., Wang, Y., Shutthanandan, V., Molina, L. T., Abraham, R. G., Johnson, K. S., Mugica, V., Molina, M. J., Laskin, A., and Prather, K. A.: Characterization of Aerosols Containing Zn, Pb, and $\mathrm{Cl}$ from an Industrial Region of Mexico City, Environ. Sci. Technol., 42, 7091-7097, https://doi.org/10.1021/es7030483, 2008a.

Moffet, R. C., de Foy, B., Molina, L. T., Molina, M. J., and Prather, K. A.: Measurement of ambient aerosols in northern Mexico City by single particle mass spectrometry, Atmos. Chem. Phys., 8, 4499-4516, https://doi.org/10.5194/acp-8-4499-2008, 2008b. 
Moldanová, J., Fridell, E., Popovicheva, O., Demirdjian, B., Tishkova, V., Faccinetto, A., and Focsa, C.: Characterisation of particulate matter and gaseous emissions from a large ship diesel engine, Atmos. Environ., 43, 2632-2641, https://doi.org/10.1016/j.atmosenv.2009.02.008, 2009.

Monn, C., Braendli, O., and Schaeppi, G.: Particulate matter $<10 \mu \mathrm{m}\left(\mathrm{PM}_{10}\right)$ and total suspended particulates (TSP) in urban, rural and alpine air in Switzerland, Atmos. Environ., 29, 25652573, https://doi.org/10.1016/1352-2310(95)94999-U, 1995.

Müller, C., Iinuma, Y., Karstensen, J., van Pinxteren, D., Lehmann, S., Gnauk, T., and Herrmann, H.: Seasonal variation of aliphatic amines in marine sub-micrometer particles at the Cape Verde islands, Atmos. Chem. Phys., 9, 9587-9597, https://doi.org/10.5194/acp-9-9587-2009, 2009.

Neubauer, K. R., Johnston, M. V., and Wexler, A. S.: On-line analysis of aqueous aerosols by laser desorption ionization, Int. J. Mass Spectrom., 163, 29-37, https://doi.org/10.1016/S01681176(96)04534-X, 1997.

Neubauer, K. R., Johnston, M. V., and Wexler, A. S.: Humidity effects on the mass spectra of single aerosol particles, Atmos. Environ., 32, 2521-2529, https://doi.org/10.1016/S13522310(98)00005-3, 1998.

O’Dowd, C. D., Facchini, M. C., Cavalli, F., Ceburnis, D., Mircea, M., Decesari, S., Fuzzi, S., Yoon, Y. J., and Putaud, J.-P.: Biogenically driven organic contribution to marine aerosol, Nature, 431, 676-680, https://doi.org/10.1038/nature02959, 2004.

Pagels, J., Dutcher, D. D. D. D., Stolzenburg, M. R. M. R., Mcmurry, P. H. P. H., Gälli, M. E. M. E., and Gross, D. S. D. S.: Fineparticle emissions from solid biofuel combustion studied with single-particle mass spectrometry: Identification of markers for organics, soot, and ash components, J. Geophys. Res.-Atmos., 118, 859-870, https://doi.org/10.1029/2012JD018389, 2013.

Pey, J., Querol, X., and Alastuey, A.: Discriminating the regional and urban contributions in the North-Western Mediterranean: PM levels and composition, Atmos. Environ., 44, 1587-1596, https://doi.org/10.1016/j.atmosenv.2010.02.005, 2010.

Pratt, K. A. and Prather, K. A.: Real-Time, Single-Particle Volatility, Size, and Chemical Composition Measurements of Aged Urban Aerosols, Environ. Sci. Technol., 43, 8276-8282, https://doi.org/10.1021/es902002t, 2009.

Pratt, K. A. and Prather, K. A.: Mass spectrometry of atmospheric aerosols-Recent developments and applications. Part II: On-line mass spectrometry techniques, Mass Spectrom. Rev., 31, 17-48, https://doi.org/10.1002/mas.20330, 2012.

Pratt, K. A., Hatch, L. E., and Prather, K. A.: Seasonal volatility dependence of ambient particle phase amines, Environ. Sci. Technol., 43, 5276-5281, 2009.

Pratt, K. A., Heymsfield, A. J., Twohy, C. H., Murphy, S. M., DeMott, P. J., Hudson, J. G., Subramanian, R., Wang, Z., Seinfeld, J. H., and Prather, K. A.: In Situ Chemical Characterization of Aged Biomass-Burning Aerosols Impacting Cold Wave Clouds, J. Atmos. Sci., 67, 2451-2468, https://doi.org/10.1175/2010JAS3330.1, 2010.

Qin, X. and Prather, K. A.: Impact of biomass emissions on particle chemistry during the California Regional Particulate Air Quality Study, Int. J. Mass Spectrom., 258, 142-150, https://doi.org/10.1016/j.ijms.2006.09.004, 2006.

Qin, X., Bhave, P. V., and Prather, K. A.: Comparison of two methods for obtaining quantitative mass concentrations from aerosol time-of-flight mass spectrometry measurements, Anal. Chem., 78, 6169-6178, https://doi.org/10.1021/ac060395q, 2006.

Qin, X., Pratt, K. A., Shields, L. G., Toner, S. M., and Prather, K. A.: Seasonal comparisons of single-particle chemical mixing state in Riverside, CA, Atmos. Environ., 59, 587-596, https://doi.org/10.1016/j.atmosenv.2012.05.032, 2012.

Querol, X., Alastuey, A., Puicercus, J. A., Mantilla, E., Ruiz, C. R., Lopez-Soler, A., Plana, F., and Juan, R.: Seasonal evolution of suspended particles around a large coal-fired power station: Chemical characterization, Atmos. Environ., 32, 719-731, https://doi.org/10.1016/S1352-2310(97)00340-3, 1998a.

Querol, X., Alastuey, A., Puicercus, J. A., Mantilla, E., Miro, J. V., Lopez-Soler, A., Plana, F., and Artiñano, B.: Seasonal evolution of suspended particles around a large coal-fired power station: Particulate levels and sources, Atmos. Environ., 32, 1963-1978, https://doi.org/10.1016/S1352-2310(97)00504-9, 1998b.

Querol, X., Alastuey, A., Rodríguez, S., Viana, M. M., Artíñano, B., Salvador, P., Mantilla, E., Do Santos, S. G., Patier, R. F., De La Rosa, J., De La Campa, A. S., Menéndez, M., and Gil, J. J.: Levels of particulate matter in rural, urban and industrial sites in Spain, Sci. Total Environ., 334-335, 359-376, https://doi.org/10.1016/j.scitotenv.2004.04.036, 2004.

Querol, X., Alastuey, A., Pey, J., Cusack, M., Pérez, N., Mihalopoulos, N., Theodosi, C., Gerasopoulos, E., Kubilay, N., and Koçak, M.: Variability in regional background aerosols within the Mediterranean, Atmos. Chem. Phys., 9, 4575-4591, https://doi.org/10.5194/acp-9-4575-2009, 2009.

Rehbein, P. J. G., Jeong, C. H., McGuire, M. L., Yao, X., Corbin, J. C., and Evans, G. J.: Cloud and fog processing enhanced gas-toparticle partitioning of trimethylamine, Environ. Sci. Technol., 45, 4346-4352, https://doi.org/10.1021/es1042113, 2011.

Reinard, M. and Johnston, M.: Ion formation mechanism in laser desorption ionization of individual nanoparticles, J. Am. Soc. Mass Spectrom., 19, 389-399, https://doi.org/10.1016/j.jasms.2007.11.017, 2008.

Reinard, M. S., Adou, K., Martini, J. M., and Johnston, M. V.: Source characterization and identification by real-time single particle mass spectrometry, Atmos. Environ., 41, 9397-9409, https://doi.org/10.1016/j.atmosenv.2007.09.001, 2007.

Renard, J.-B., Dulac, F., Berthet, G., Lurton, T., Vignelles, D., Jégou, F., Tonnelier, T., Jeannot, M., Couté, B., Akiki, R., Verdier, N., Mallet, M., Gensdarmes, F., Charpentier, P., Mesmin, S., Duverger, V., Dupont, J.-C., Elias, T., Crenn, V., Sciare, J., Zieger, P., Salter, M., Roberts, T., Giacomoni, J., Gobbi, M., Hamonou, E., Olafsson, H., Dagsson-Waldhauserova, P., Camy-Peyret, C., Mazel, C., Décamps, T., Piringer, M., Surcin, J., and Daugeron, D.: LOAC: a small aerosol optical counter/sizer for ground-based and balloon measurements of the size distribution and nature of atmospheric particles - Part 2: First results from balloon and unmanned aerial vehicle flights, Atmos. Meas. Tech., 9, 36733686, https://doi.org/10.5194/amt-9-3673-2016, 2016.

Rodríguez, S., Querol, X., and Alastuey, A.: Saharan dust contributions to $\mathrm{PM}_{10}$ and TSP levels in Southern and Eastern Spain, Atmos. Environ., 35, 2433-2447, https://doi.org/10.1016/S13522310(00)00496-9, 2001.

Rodríguez, S., Querol, X., Alastuey, A., and Plana, F.: Sources and processes affecting levels and composition of atmospheric aerosol in the western Mediterranean, J. Geophys. Res.-Atmos., 107, 1-14, https://doi.org/10.1029/2001JD001488, 2002. 
Rodríguez, S., Querol, X., Alastuey, A., and de la Rosa, J.: Atmospheric particulate matter and air quality in the Mediterranean: A review, Environ. Chem. Lett., 5, 1-7, https://doi.org/10.1007/s10311-006-0071-0, 2007.

Röösli, M., Theis, G., Künzli, N., Staehelin, J., Mathys, P., Oglesby, L., Camenzind, M., and Braun-Fahrländer, C.: Temporal and spatial variation of the chemical composition of $\mathrm{PM}_{10}$ at urban and rural sites in the Basel area, Switzerland, Atmos. Environ., 35, 3701-3713, https://doi.org/10.1016/S1352-2310(00)005112, 2001.

Royer, P., Raut, J.-C., Ajello, G., Berthier, S., and Chazette, P.: Synergy between CALIOP and MODIS instruments for aerosol monitoring: application to the Po Valley, Atmos. Meas. Tech., 3, 893 907, https://doi.org/10.5194/amt-3-893-2010, 2010.

Salameh, D., Detournay, A., Pey, J., Pérez, N., Liguori, F., Saraga, D., Bove, M. C., Brotto, P., Cassola, F., Massabò, D., Latella, A., Pillon, S., Formenton, G., Patti, S., Armengaud, A., Piga, D., Jaffrezo, J. L., Bartzis, J., Tolis, E., Prati, P., Querol, X., Wortham, H., and Marchand, N.: $\mathrm{PM}_{2.5}$ chemical composition in five European Mediterranean cities: A 1-year study, Atmos. Res., 155, 102-117, https://doi.org/10.1016/j.atmosres.2014.12.001, 2015.

Salvador, R., Calbó, J., and Millán, M. M.: Horizontal grid size selection and its influence on mesoscale model simulations, J. Appl. Meteorol., 38, 1311-1329, https://doi.org/10.1175/15200450(1999)038<1311:HGSSAI >2.0.CO;2, 1999.

Scheeren, H. A., Lelieveld, J., Roelofs, G. J., Williams, J., Fischer, H., de Reus, M., de Gouw, J. A., Warneke, C., Holzinger, R., Schlager, H., Klüpfel, T., Bolder, M., van der Veen, C., and Lawrence, M.: The impact of monsoon outflow from India and Southeast Asia in the upper troposphere over the eastern Mediterranean, Atmos. Chem. Phys., 3, 1589-1608, https://doi.org/10.5194/acp-3-1589-2003, 2003.

Sciare, J., Cachier, H., Oikonomou, K., Ausset, P., Sarda-Estève, R., and Mihalopoulos, N.: Characterization of carbonaceous aerosols during the MINOS campaign in Crete, July-August 2001: a multi-analytical approach, Atmos. Chem. Phys., 3, 1743 1757, https://doi.org/10.5194/acp-3-1743-2003, 2003.

Sciare, J., Oikonomou, K., Favez, O., Liakakou, E., Markaki, Z., Cachier, H., and Mihalopoulos, N.: Long-term measurements of carbonaceous aerosols in the Eastern Mediterranean: evidence of long-range transport of biomass burning, Atmos. Chem. Phys., 8, 5551-5563, https://doi.org/10.5194/acp-8-5551-2008, 2008.

Sellegri, K., Pey, J., Rose, C., Culot, A., DeWitt, H. L., Mas, S., Schwier, A. N., Temime-Roussel, B., Charriere, B., SaizLopez, A., Mahajan, A. S., Parin, D., Kukui, A., Sempere, R., D'Anna, B., and Marchand, N.: Evidence of atmospheric nanoparticle formation from emissions of marine microorganisms, Geophys. Res. Lett., 43, 6596-6603, https://doi.org/10.1002/2016GL069389, 2016.

Silva, P. J. and Prather, K. A.: On-Line Characterization of Individual Particles from Automobile Emissions, Environ. Sci. Technol., 31, 3074-3080, https://doi.org/10.1021/es961063d, 1997.

Silva, P. J. and Prather, K. A.: Interpretation of mass spectra from organic compounds in aerosol time-offlight mass spectrometry, Anal. Chem., 72, 3553-3562, https://doi.org/10.1021/ac9910132, 2000.

Silva, P. J., Liu, D.-Y., Noble, C. A., and Prather, K. A.: Size and Chemical Characterization of Individual Particles Resulting from Biomass Burning of Local Southern
California Species, Environ. Sci. Technol., 33, 3068-3076, https://doi.org/10.1021/es980544p, 1999.

Silva, P. J., Carlin, R. A., and Prather, K. A.: Single particle analysis of suspended soil dust from Southern California, Atmos. Environ., 34, 1811-1820, https://doi.org/10.1016/S13522310(99)00338-6, 2000.

Song, X. H., Klaas, N., Faber, M., Hopke, P. K., Suess, D. T., Prather, K. A., Schauer, J. J., and Cass, G. R.: Source apportionment of gasoline and diesel by multivariate calibration based on single particle mass spectral data, Anal. Chim. Ac., 446, 329343, https://doi.org/10.1016/S0003-2670(01)01270-3, 2001.

Soriano, C., Baldasano, J. M., Buttler, W. T., and Moore, K. R.: Circulatory patterns of air pollutants within the Barcelona air basin in a summertime situation: lidar and numerical approaches, Bound.-Lay. Meteorol., 98, 33-55, https://doi.org/10.1023/A:1018726923826, 2001.

Sorooshian, A., Padro, L. T., Nenes, A., Feingold, G., McComiskey, A., Hersey, S. P., Gates, H., Jonsson, H. H., Miller, S. D., Stephens, G. L., Flagan, R. C., and Seinfeld, J. H.: On the link between ocean biota emissions, aerosol, and maritime clouds: Airborne, ground, and satellite measurements off the coast of California, Global Biogeochem. Cy., 23, 1-15, https://doi.org/10.1029/2009GB003464, 2009.

Spencer, M. and Prather, K. A.: Using ATOFMS to Determine OC/EC Mass Fractions in Particles, Aerosol Sci. Tech., 40, 585 594, https://doi.org/10.1080/02786820600729138, 2006.

Spencer, M., Holecek, J. C., Corrigan, C. E., Ramanathan, V., and Prather, K. A.: Size-resolved chemical composition of aerosol particles during a monsoonal transition period over the Indian Ocean, J. Geophys. Res., 113, 1-14, https://doi.org/10.1029/2007JD008657, 2008.

Steele, P. T., Srivastava, A., Pitesky, M. E., Fergenson, D. P., Tobias, H. J., Gard, E. E., and Frank, M.: Desorption/ionization fluence thresholds and improved mass spectral consistency measured using a flattop laser profile in the bioaerosol mass spectrometry of single Bacillus endospores, Anal. Chem., 77, 74487454, https://doi.org/10.1021/ac051329b, 2005.

Su, Y., Sipin, M. F., Furutani, H., and Prather, K. A.: Development and Characterization of an Aerosol Time-of-Flight Mass Spectrometer with Increased Detection Efficiency, Anal. Chem., 76, 712-719, https://doi.org/10.1029/2001JD001211, 2004.

Sullivan, R. C. and Prather, K. A.: Investigations of the diurnal cycle and mixing state of oxalic acid in individual particles in Asian aerosol outflow, Environ. Sci. Technol., 41, 8062-8069, https://doi.org/10.1021/es071134g, 2007.

Sullivan, R. C., Guazzotti, S. A., Sodeman, D. A., and Prather, K. A.: Direct observations of the atmospheric processing of Asian mineral dust, Atmos. Chem. Phys., 7, 1213-1236, https://doi.org/10.5194/acp-7-1213-2007, 2007.

Tao, S., Wang, X., Chen, H., Yang, X., Li, M., Li, L., and Zhou, Z.: Single particle analysis of ambient aerosols in Shanghai during the World Exposition, 2010: two case studies, Front. Environ. Sci. Eng. China, 5, 391-401, https://doi.org/10.1007/s11783011-0355-x, 2011.

Turnbull, A. B. and Harrison, R. M.: Major component contributions to $\mathrm{PM}_{10}$ composition in the UK atmosphere, Atmos. Environ., 34, 3129-3137, https://doi.org/10.1016/S13522310(99)00441-0, 2000. 
Wang, X., Ye, X., Chen, H., Chen, J., Yang, X., and Gross, D. S.: Online hygroscopicity and chemical measurement of urban aerosol in Shanghai, China, Atmos. Environ., 95, 318-326, https://doi.org/10.1016/j.atmosenv.2014.06.051, 2014.

Wenzel, R. J. and Prather, K. A.: Improvements in ion signal reproducibility obtained using a homogeneous laser beam for on-line laser desorption/ionization of single particles, Rapid Commun. Mass Sp., 18, 1525-1533, https://doi.org/10.1002/rcm.1509, 2004.

Whiteaker, J. R. and Prather, K. A.: Hydroxymethanesulfonate as a tracer for fog processing of individual aerosol particles, Atmos. Environ., 37, 1033-1043, https://doi.org/10.1016/S13522310(02)01029-4, 2003

Willis, M. D., Burkart, J., Thomas, J. L., Köllner, F., Schneider, J., Bozem, H., Hoor, P. M., Aliabadi, A. A., Schulz, H., Herber, A. B., Leaitch, W. R., and Abbatt, J. P. D.: Growth of nucleation mode particles in the summertime Arctic: a case study, Atmos. Chem. Phys., 16, 7663-7679, https://doi.org/10.5194/acp16-7663-2016, 2016.

Wyslouzil, B. E., Seinfeld, J. H., Flagan, R. C., and Okuyama, K.: Binary nucleation in acid-water systems. I. Methanesulfonic acid-water, J. Chem. Phys., 94, 6827, https://doi.org/10.1063/1.460261, 1991a.

Wyslouzil, B. E., Seinfeld, J. H., Flagan, R. C., and Okuyama, K.: Binary nucleation in acid-water systems. II. Sulfuric acid-water and a comparison with methanesulfonic acid-water, J. Chem. Phys., 94, 6842, https://doi.org/10.1063/1.460262, 1991b.
Yang, F., Chen, H., Wang, X., Yang, X., Du, J., and Chen, J.: Single particle mass spectrometry of oxalic acid in ambient aerosols in Shanghai: Mixing state and formation mechanism, Atmos. Environ., 43, 3876-3882, https://doi.org/10.1016/j.atmosenv.2009.05.002, 2009.

Yu, J. Z., Huang, X.-F., Xu, J., and Hu, M.: When aerosol sulfate goes up, so does oxalate: implication for the formation mechanisms of oxalate, Environ. Sci. Technol., 39, 128-133, https://doi.org/10.1021/es049559f, 2005.

Zhang, Q., Jimenez, J. L., Canagaratna, M. R., Ulbrich, I. M., Ng, N. L., Worsnop, D. R., and Sun, Y.: Understanding atmospheric organic aerosols via factor analysis of aerosol mass spectrometry: A review, Anal. Bioanal. Chem., 401, 3045-3067, https://doi.org/10.1007/s00216-011-5355-y, 2011.

Zhang, Y., Wang, X., Chen, H., Yang, X., Chen, J., and Allen, J. O.: Source apportionment of leadcontaining aerosol particles in Shanghai using single particle mass spectrometry, Chemosphere, 74, 501-507, https://doi.org/10.1016/j.chemosphere.2008.10.004, 2009.

Zhu, S., Sartelet, K. N., Healy, R. M., and Wenger, J. C.: Simulation of particle diversity and mixing state over Greater Paris: a modelmeasurement inter-comparison, Faraday Discuss., 189, 547-566, https://doi.org/10.1039/c5fd00175g, 2016. 